\title{
National innovative capacity in the water sector: A comparison between China and
} Europe

Moro, Mariú Abritta; Andersen, Maj Munch; Smets, Barth F.; McKnight, Ursula S.

Published in:

Journal of Cleaner Production

Link to article, DOI:

10.1016/j.jclepro.2018.10.329

Publication date:

2019

Document Version

Peer reviewed version

Link back to DTU Orbit

Citation (APA):

Moro, M. A., Andersen, M. M., Smets, B. F., \& McKnight, U. S. (2019). National innovative capacity in the water sector: A comparison between China and Europe. Journal of Cleaner Production, 210, 325-342.

https://doi.org/10.1016/j.jclepro.2018.10.329

\section{General rights}

Copyright and moral rights for the publications made accessible in the public portal are retained by the authors and/or other copyright owners and it is a condition of accessing publications that users recognise and abide by the legal requirements associated with these rights.

- Users may download and print one copy of any publication from the public portal for the purpose of private study or research.

- You may not further distribute the material or use it for any profit-making activity or commercial gain

- You may freely distribute the URL identifying the publication in the public portal 


\section{National Innovative capacity in the water sector: An analysis of China and Europe}

${ }^{1}$ Department of Environmental Engineering, Technical University of Denmark, Bygningstorvet 115, 2800 Kgs. Lyngby, Denmark.

2 Sino-Danish Center for Education and Research. University of Chinese Academy of Sciences 380 Huaibeizhuang, Huairou district, Beijing, China.

${ }^{3}$ Department of Management Engineering, Technical University of Denmark, Diplomvej Building 372, 2800 Kgs. Lyngby, Denmark.

*Corresponding author: mamor@env.dtu.dk

\section{Abstract}

The water sector needs to increase its resource efficiency; failure to do so may have negative effects on economic development and growth. Achieving a higher level of innovative capacity within the water sector may govern a country's capacity to meet specific water challenges and ensure sustainable economic development. Traditional water technologies are reaching their stagnation point; in a transition to more sustainable technologies, eco-innovation is the core driver. Based on the national innovative capacity (NIC) as an analytical framework, we test indicators that govern the innovative capacity of the water sector in Europe versus China, representing respectively, an early mover and a late mover in the green economy agenda. Additionally, we provide an analysis of the evolution of the water technological development. We found that the innovative capacity in the water sector is strongly related to the national innovative strategy. Environmental regulations, Research and Development and international collaboration were all found to be determinants for both Europe's and China's NIC in the water sector. The level of direct investments and private Research and Development, on the other hand, were found to be a determinant for China only. However, the evolution of the NIC determinants could not provide any insight as to whether China may reach the same level of NIC in the water sector as Europe. This analysis contributes nonetheless to increasing the level of understanding in the water innovation dynamics field, providing insights related as to why Europe and China present different innovative capacities in the water sector.

Keywords: National innovative capacity, eco-innovations, water technologies, water sector, China, Europe. 


\section{Introduction}

Water is essential for human life, yet in 2010 , more than $13 \%$ of the world's population did not have access to piped water supply and/or clean water, and water demand is predicted to increase more than $55 \%$ by 2050 due to both population and economic growth (OECD, 2012a). The capacity of a country to increase its efficient use of natural resources via technological development will impact its overall economic development and growth in the long run (United Nations Environmental Program (UNEP), 2011). Technological developments in the water sector are essential for enabling the transition to more sustainable economies (OECD, 2012b), and understanding the mechanisms determining the national innovative capacity in the water sector are crucial to ensure a successful transition towards greener economies.

There is little information on what may determine the innovative capacity in the water sector. A recent study by the European Commission (2016) showed that, in Europe, the sector is highly concentrated with a few large companies dominating national markets, and is less dynamic and innovative than other comparable sectors. The report further suggests that there exists a high potential for innovation that is not being exploited. One reason for this low level of innovation could be that investments are linked with public budgets, which are influenced by economic fluctuations and government instabilities (European Commission, 2016).

This paper analyses water eco-innovation, with a special focus on testing whether the national innovative capacity in water varies with a country's stage into the greening of the innovation system. Specifically, we investigate whether countries in different stages of development display different water innovation system characteristics, and whether the drivers for enhancing innovative capacity are therefore different. The comparison between Europe and China represents a special case to be analyzed, since Europe is an early mover in the green economy agenda (Andersen, 2010a), whereas China is a late mover.

This paper therefore analyzes the drivers of the national innovative capacity (NIC) in the water sector and examines whether indicators recognized as important drivers for NIC as a whole could also be applicable 
for the water sector. In addition, the role of environmental regulations and environmental indicators on the NIC of the water sector is examined. Finally, Europe and China are compared to identify differences in drivers of the innovative capacity in this sector.

\section{Background}

The concept of innovative capacity was formally introduced by (Suarez-Villa, 1990) as a measure of the level of invention and the innovative potential, the current and potential capabilities of a system to convert knowledge into innovation, and sustain its development (Freeman, 1995; Furman et al., 2002; Lundvall and Johnson, 1994; Schiuma and Lerro, 2008). Linked to these ideas, the concept of a national innovative capacity (NIC) was introduced (Furman et al., 2002; Porter and Stern, 1998). The NIC can be understood as the ability of a country to produce and commercialize a flow of innovative technology over the long term (Furman et al., 2002); NIC is more than the realized level of innovative output per se, reflecting also the drivers of the innovation process (Furman et al., 2002). According to Furman et al. (2002), the NIC is determined by the interaction of: (i) the common innovation infrastructure, which represents the framework conditions for technological development, such as the education infrastructure and the size of the economy; (ii) the clusterspecific environment for innovation, as housed in companies and knowledge institutions; (iii) the quality of the linkage between the cluster-specific environment and the common innovation infrastructure.

The framework used by Furman et.al (2002) empirically explores the determinants of country differences on the innovation intensity levels, by analyzing the relationship between the level of patenting activities and variables related to NIC, such as the common innovation infrastructure and the cluster-specific environment. The framework to analyze the NIC is based primarily on the national innovation system (Lundvall, 1998), but also on the endogenous growth theory (Romer, 1990) and the cluster-based theory (Porter and Stern, 1998). National innovation system (NIS) theory focuses on the direction and intensity of knowledge flows, technology transfer, commercialization of knowledge and economic incentives (Lundvall, 1998) which additionally enables a country comparison (Nelson, 1993, 1992). The endogenous growth theory (Romer, 1990) focus on levels of knowledge stocks and aggregate indicator levels, such as R\&D and labour, and the 
cluster-based theory of national industrial competitive advantage focuses on the micro-economic dynamics and inter-actor's interactions. The Furman et al. (2002) NIC analytical framework can therefore be used to contrast innovation capacities from country to country. In this context, the ability to develop cross-country comparisons is extremely important for investigating why countries present different innovative capacities, a question still not addressed for the water sector.

\subsection{National innovative capacity applied to the European context}

Since the pioneering work of Furman et al. (2002), the NIC analytical framework has been used in many different contexts. Suarez-Villa et al. (2003) provided two types of innovative performance based on the interaction between inter-organizational networks and the innovative capacity. Riddel and Schwer (2003) analysed the endogenous relationship between employment growth and the NIC in the United States. Faber and Hesen (2004) tested the NIC framework for 14 EU countries and added sales of product innovations to the analysis. Archibugi and Coco (2005) analysed the differences in methodologies for NIC analysis used by organizations such as the World Economic Forum, the United Nations, and the European Commission and found inconsistencies among the methodologies making it difficult to develop comparisons. Natário et al. (2007) analysed the evolution of the NIC among European countries, adding variables from the innovation scorebook and variables related to the influence of cultural aspects and institutional differences; they found positive effects on NIC associated with the efficiency of the national institutions, and a low power distance national culture.

Castellacci and Natera $(2013,2011)$ added the dynamic aspect of the national innovation system (Lundvall, 2007) improving the analytical rigor of Furman et at. (2002). They identified that the NIC dynamics are driven by three innovative capability factors: innovative, scientific and technological input, and three absorptive capacity factors: infrastructures, international trade and human capital. Proksch et al. (2017) described different paths to improve the NIC in European countries, showing how the different compositions of the common innovation infrastructure and the cluster-specific environment can lead to the same level of 
innovation capacity. Their study revealed that the NIC is mostly associated with a combination of high GDP per capita and the share of government expenditure on higher education, and when included with the combination of high patent stock and high IP protection tends to have higher innovative output.

\subsection{National innovative capacity in developing countries}

Systemic differences exist between the innovation systems in developed versus developing or transitional economies (Gu and Lundvall, 2006; Hu and Mathews, 2005; Liu and White, 2001; Radosevic, 2002). The very stage of development per se is a reflection of these differences, for instance, companies play a major role in the NIS of developed countries, but not necessarily in developing countries where the government and foreign actors may also play an equally important role. The NIS of developing countries are also transitioning (like the economy) and therefore often lack strong innovative and R\&D capabilities and display limited absorptive capacity to transform knowledge into innovations (Fagerberg et al., 2007; Gu et al., 2016)

Hu and Mathews (2005) analysed the technological catching-up process of East-Asian countries via an increase of their NIC, measured per Furman et al. (2002), highlighting the importance of public R\&D on the development of a developing country's NIC. Mathews and Hu (2007) furthermore demonstrated the contribution of academic innovations to Taiwan's NIC, as they transitioned from a strategy of fast follower to a strategy of innovation-based developer. Hu and Matheus (2008) investigated drivers behind the Chinese NIC focusing on the relationship between China's patents and its relationship to the NIC evolution, and concluded that both the government and the universities were major actors in promoting the NIC in China. Fan( 2011) analysed NIC in India and China and concluded that human resources in R\&D, the financial investments, and the role of the government on directing investments to the national development process were crucial to the transformation of the NIC in both countries. Despite the fact that the NIC has been applied in different contexts, there is still a lack of studies analysing the NIC with a focus on sustainable development. 
Eco-innovation can be seen as the part of the process of technological and economy change in which paradigmatic changes happen in an evolutionary process. Hence eco-innovation can be understood as a process of technological and economic change related to the greening of the economy (Andersen, 2010b). In the context of a greening economy, part of the NIC is linked with the ability of a country to produce and commercialize a flow of eco-innovation technology over the long term. The eco-innovations are new or modified products or services that generate positive externalities on the environment, and are intrinsically connected with the policies of green growth, symbolizing a synergy between environment and innovation policies (Andersen, 2006; Kemp and Andersen, 2004; OECD, 2009) and the creation of green business opportunities (Andersen, 2010a; Beltramello et al., 2013). The degree of a sector's eco-innovativeness is not only driven by a self-interested search for reduced production costs, increased efficiency, or enhanced product performance, but is often controlled by public or private incentives and policies to set technological trajectory directions (Kemp and Pearson, 2007). The elements that influence eco-innovation development also differ between those related to the development of traditional innovations (Arundel and Kemp, 2009; Kemp, 2010). Environmental regulations can be a major driver of eco-innovation through breaking the technological lock-in created by uncertainties related to new technological paths (Porter and Linde, 1995). With new regulations, emerging markets are created which provide competitive advantages for new (green) technologies (Foxon and Kemp, 2008), thereby creating a win-win scenario subsumed in Porter and Linde (1995). Eco-innovations, whose development was spurred by regulations, can then generate both economic and environmental benefits, negating the oft-assumed trade-offs between private profit and environmental improvement.

The successful development of eco-innovations, however, is not only a response to environmental regulations, but is governed to a large extent (just like the development of traditional innovations) by how companies and knowledge institutions interact as a system, thereby determining the capabilities required for successful innovation activities (Carlsson et al., 2002; Edquist, 2006; Lundvall et al., 2009). In the water sector, the lack of effectiveness with respect to the interaction among key innovative actors in the sector is seen as 
153 a chief barrier for increasing the innovative capacity (De Montalvo and Alaerts, 2013). Indeed, effective interactions for a successful technological development are required among water users (citizens), water researchers, water providers (utilities companies) and water policy and regulatory bodies (governmental institutions), and even within the government bodies, many layers of interactions exist (from cities, municipalities, villages to states, provinces, regions to the national level). The high complexity inherently relies on the coordination of these different levels of interactions, and good water governance is pointed out as the solution for the barrier created by lack of effective interaction among actors in the water sector (Alaerts and Kaspersma, 2009; De Montalvo and Alaerts, 2013).

Overall, issues related to increasing the NIC for the water sector can be related to the weak link between the common innovation structure and the cluster-specific environment. An example of this weakness is the failure to coordinate efforts between governmental levels, companies and knowledge institutions increase the capabilities related to technological development of (eco) innovation. Hence, in addition to current determinants for the NIC, both the governance and the environmental policy are expected to have a strong impact on the innovative capacity of the water sector.

\section{Methods and data}

The methodology applied in this paper is built on earlier work regarding innovative capacity and in particular on the framework for innovative capacity developed by Furman et al. (2002). The determinants of NIC can thus be divided into three main categories: (i) the common innovation structure, (ii) the clusterspecific innovation environment, and (iii) the quality of linkages. The overall innovative performance of an economy will result from the interplay among all three (Furman et al., 2002). For example, the common innovation infrastructure creates a positive or hostile environment for technological development, whereas a strong or weak cluster innovation environment can enhance or hinder the strengths of the common innovation infrastructure. 

that have previously used patents as a proxy for innovation to measure innovative capacity e.g (Faber and Hesen, 2004; Furman et al., 2002; Krammer, 2009; Mellahi and Wilkinson, 2010). Patents are useful in this context because they provide a highly disaggregated level of information and still enable the comparison across different countries. It should be mentioned that several limitations are commonly recognized when using patents as a proxy for innovation, for example, not all patents may reflect an innovation and/or there may be important innovations that are not patentable. The limitations of patents as a proxy for the level of water innovative capacity have been extensively debated elsewhere (Archibugi, 1992; Griliches et al., 1986; Pavitt, 1985), and are therefore not discussed further in this paper; we firmly believe that patent counts can be successfully applied as a proxy for the level of innovation activity and to analyze changes in the technological trajectory especially when considering the limited data available in the water sector (Moro et al., 2018).

\subsection{Data collection}

Data has been collected from the Organization for Economic Co-operation and Development (OECD) and the European Patent Office (EPO), since previous work showed no differences in variance explained using the data of the EPO compared to the US Patent Office (USPTO) (Faber and Hesen, 2004). Furthermore, we have specifically used Triades ${ }^{1}$ patent data covering the timeframe from 1990 until 2013, thereby allowing us to additionally investigate and capture the changes over time. This database can distinguish patent families, which prevents counting the same invention multiple times and ensures that only high level patents were included in our analysis. To further avoid low quality patents, we selected only granted patents that were filed with the EPO, USPTO, and World Intellectual Property Organization (WIPO). Moreover, the patents have

\footnotetext{
${ }^{1}$ According to OECD, the triadic patent families are counted according to the earliest priority date (first patent application worldwide), the inventor's country of residence and fractional counts. The OECD triadic patent families improve the quality and the international comparability of a patent indicator; home advantage and influence of geographical location are eliminated (OECD, 2009).
} 
been collected using the International Patent Classification (IPC) codes, and these selected IPC codes are part of the EPO environmental technologies classification.

The initial variables introduced by Furman et al. (2002) and further elaborated by Proksch et al. (2016) are kept. However, due to the selection of regions studied here (i.e. Europe and China), the sectoral choice (water) and the available data, the analysis had to be modified in order to improve the analysis of the national innovative capacity framework to be applied in the water sector. The other indicators used in this study were mainly collected from the OECD database in order to ensure quality level of data. A comprehensive overview of the variables explored in this study is available in the Appendix (Table A.2).

\subsubsection{Variables to measure the NIC} International water patents and international water patents per capita (IWPPC)

$$
\text { The water patents are selected based on a list of specific IPC codes related to water environmental-related }
$$
technologies (See appendix Table A.3) and were counted based on the triadic patent families. The water patents per capita is then calculated according to equation (1), where $i=$ country and $j=$ specific year:

$$
I W P P C_{i, j}=\frac{\sum \text { Water patents }_{i, j}}{\sum \text { Population per head } \text { he }_{i, j}}
$$

\subsubsection{Common innovation infrastructure}

GDP per capita

Given the choice to analyze European countries and China, the common way of calculating the GDP is via US dollars purchasing power parities (PPP). The PPP and related economic indicators are constructed primarily for spatial comparison and for comparison between different currency areas (Eurostats, 2015).

\section{Stock of international water patents (SIWP)}

If the maximum lifetime of a patent is 20 years, records from a 20 -year period would allow assessment of the influence of a patent stock. Also, a consistent database is available for only about two decades, enabling 
us to accumulate all patents within a 23-year period for each observed point in time (1990-2014). The stock of international patents is then calculated using the formula below, where $i=$ country and $j=$ specific year:

$$
\operatorname{SIWP}_{i, j}=\sum \text { Water patents } s_{i, j+1}
$$

Aggregate employed scientific and technological (S\&T) personnel and labor force

The S\&T head count data measures the total number of researchers who are fully or partly employed within R\&D (OECD, 2015)

\section{Aggregate R\&D expenditures}

The aggregate R\&D expenditures have been extracted from the OECD Database and are in US dollars. The R\&D statistics are based on the main concepts and definitions of the OECD (2002), which is an internationally recognized standard methodology for collecting R\&D statistics.

\section{Strength of protection for Intellectual Property (IP)}

The strength of IP rights was measured using the intellectual property rights index extracted from the intellectual property rights organization. The values vary from 0 (weak IP rights) to 20 (strong IP rights); the higher the IPRI value, the greater the IP protection within a country.

\section{Share of government expenditure on higher education}

The share of government expenditure on higher education, extracted from the OECD database, is presented as a percentage of the GDP.

\section{Specialization degree}

238 The specialization degree is calculated by dividing the number of water patents per total number of patents.

239 The patents are classified according to the IPC codes. The specialization index is calculated according to equation (3), where $i=$ country and $j=$ specific year: 


\subsubsection{Additional variables to measure the NIC for the water sector}

243 The driver for eco-innovation development may differ from traditional technologies, where environmental 244 regulations are recognized as key drivers for eco-innovation (Foxon and Kemp, 2008; Gregersen and Johnson, 245 2009; Porter and Linde, 1995), but are not limited to a response to the regulations. Therefore, we included a 246 set of variables in our analysis for testing whether they display a relationship (correlation) with the level of 247 NIC in the water sector. The selection of these variables is based on a literature review of water and 248 (eco)innovations.

\section{Environmental Policy Stringency Index ${ }^{2}$ (EPS index)}

The OECD Environmental Policy Stringency index is a country-specific and internationally comparable measure of the stringency of environmental policy. Stringency is defined as the degree to which environmental policies put an explicit or implicit price on polluting or other environmentally harmful behavior. The index ranges from 0 (not stringent) to 6 (highest degree of stringency). The index covers 28 OECD and 6 BRICS countries for the period of 1990-2013. The index is based on the degree of stringency for 25514 environmental policy instruments, primarily related to climate and air pollution (Botta and Koźluk, 2014). 256 The index is comprised of both market based and non-market based indicators.

Water dependency ratio ${ }^{3}$

The dependency ratio expresses the part of the total renewable water resources originating outside the country. This indicator may theoretically vary between $0 \%$ (the country does not receive water) and $100 \%$ (country receives all its water from outside). This indicator does not consider the possible allocation of water

\footnotetext{
2 The dedicated website: http://oe.cd/OQ

${ }^{3}$ Source: http://www.fao.org/nr/water/aquastat/data/query/index.html?lang=en
} 
261 to downstream countries, but otherwise begins to give some indication of the importance/influence of 262 transboundary waters for a country/region. The dependency ratio of a country is an indicator expressing the 263 percentage of the water resources originating outside the country. (UNEP, GEODATA, 2017)

264

\section{Drinking water availability}

This indicator reflects the percentage of the population with access to drinking water. The indicators vary from 0 (no access to drinking water) to 100 (complete access to drinking water) (UNEP, GEODATA, 2017).

\section{Water pollution levels}

The water pollution level is determined based on three indicators related to the nitrogen level (Emnox), phosphorus level (Emso2) and non-methane organic compound level (Emnvoc). The coverage of all sources/types of water pollution - typically encompassing physical changes (e.g. erosion), aesthetical pollution, eutrophication, pathogenic pressure, oxygen depletion, xenobiotic chemicals, and changes in the ecosystem (community dynamics) (Vezzaro et al., 2018) - wasn't possible due to limitations in data availability and consistency. However, the majority of European ecological indices, especially for macroinvertebrates and fish, are based on dissolved oxygen, nitrogen and phosphorous compounds targeting effects of pollution with easily degradable organic matter (Vezzaro et al., 2018), and thus the results presented here are believed to present a robust first indication for the state of pollution in surface water.

\section{Collaboration}

The paper uses the international collaboration index as a proxy for the level of interaction between domestic actors and international actors. The index is. The index is calculated by OECD as measure for the level of shared patents of a country available at disaggregated levels, enabling the use of the index specific for water patents.

\section{Governance}


The issue of water governance was pointed out as being a barrier for the development of technological capacity (De Montalvo and Alaerts, 2013). As a proxy for governance, the level of direct investments has been selected. We recognize the limitation of this indicator as a proxy for governance, since it doesn't necessarily reflects the level of government leadership on promoting the development of capabilities in the water sector, but due to the lack of quantitative data in the analyzed timeframe (1990-2013) and the selected objects (China and Europe), this was determined to be the closest variable available, since it shows the level of governmental direct investments .

\subsection{Data treatment}

First, the paper provides the descriptive statistics of the main indicators related to the level of NIC (water patents per capita and water patents), common innovation infrastructure (EPS index, collaboration, direct investments, total R\&D expenditures, GDP per capita, patent stock, investments in higher education and full time equivalents), and the cluster-specific environment (private R\&D funding and the private R\&D funding performed by universities, total R\&D and the specialization index). This first assessment of the data provides the overall evolution of the indicators which may have a relation with the level of water innovative capacity. innovative capacity. The paper first analyzes the correlation matrix and tests for multi-collinearity to exclude 
307 supplementary information. Different combinations of dependent variables were tested to identify potential 308 changes to the explanatory power of the model. Additionally, the control for year-to-capture differences over 309 time was included, as well as different models to control for fixed or random effects. The fixed and random 310 effects test can also be found in the supplementary information.

311 Table 1: Descriptive data.

\begin{tabular}{|c|c|c|c|c|c|c|c|}
\hline Variable & & Mean & Std. Dev. & Min & Max & Obser & rations \\
\hline \multirow[t]{3}{*}{ Water Patents } & overall & 2.77564 & 1.45217 & 1.1087 & 5.6621 & $N=$ & 432 \\
\hline & between & & 1.34426 & 0.63879 & 5.48376 & $\mathrm{n}=$ & 18 \\
\hline & within & & 0.63102 & 0.259063 & 5.38216 & $T=$ & 24 \\
\hline \multirow[t]{3}{*}{ IWPPC } & overall & 0.12348 & 1.6479 & 11.5129 & 1.9732 & $N=$ & 432 \\
\hline & between & & 1.53758 & 4.86415 & 1.28741 & $\mathrm{n}=$ & 18 \\
\hline & within & & 0.69109 & 6.77223 & 2.48136 & $T=$ & 24 \\
\hline \multirow[t]{3}{*}{ WPstock } & overall & 4.8565 & 1.71974 & 1.3863 & 8.6673 & $N=$ & 432 \\
\hline & between & & 1.40389 & 2.606117 & 7.70545 & $n=$ & 18 \\
\hline & within & & 1.04488 & 0.864079 & 7.30808 & $\mathrm{~T}=$ & 24 \\
\hline \multirow[t]{3}{*}{ specdgree } & overall & 3.89962 & 0.90584 & 5.8713 & 1.5349 & $N=$ & 432 \\
\hline & between & & 0.7306 & 4.5773 & 1.70966 & $\mathrm{n}=$ & 18 \\
\hline & within & & 0.56147 & -5.7949 & 1.329 & $\mathrm{~T}=$ & 24 \\
\hline \multirow[t]{3}{*}{ EPS index } & overall & 5.05017 & 0.58383 & 3.2189 & 6.0243 & $N=$ & 432 \\
\hline & between & & 0.32481 & 4.240562 & 5.5336 & $\mathrm{n}=$ & 18 \\
\hline & within & & 0.49091 & 3.831026 & 6.12851 & $T=$ & 24 \\
\hline \multirow[t]{3}{*}{ pop } & overall & 2.8869 & 1.42411 & 1.2724 & 7.2319 & $N=$ & 432 \\
\hline & between & & 1.46312 & 1.392787 & 7.16151 & $n=$ & 18 \\
\hline & within & & 0.04003 & 2.76651 & 3.03781 & $\mathrm{~T}=$ & 24 \\
\hline \multirow[t]{3}{*}{ UniRD } & overall & 2.70252 & 1.52007 & 4.0378 & 11.1044 & $N=$ & 432 \\
\hline & between & & 1.1879 & 1.2386 & 4.31819 & $n=$ & 18 \\
\hline & within & & 0.98732 & 0.19308 & 10.3295 & $\mathrm{~T}=$ & 24 \\
\hline \multirow[t]{3}{*}{ PrivRDUni } & overall & 1.209 & 1.75066 & -9.1809 & 0.0973 & $N=$ & 432 \\
\hline & between & & 0.84363 & -2.88387 & 0.41944 & $\mathrm{n}=$ & 18 \\
\hline & within & & 1.54631 & -8.95666 & 1.21457 & $T=$ & 24 \\
\hline GDPcap & overall & 10.0233 & 0.64636 & 6.8856 & 11.1132 & $\mathrm{~N}=$ & 432 \\
\hline
\end{tabular}




\begin{tabular}{|c|c|c|c|c|c|c|c|}
\hline & between & & 0.54267 & 8.180221 & 10.5154 & $\mathrm{n}=$ & 18 \\
\hline & within & & 0.37284 & 8.456046 & 11.2636 & $\mathrm{~T}=$ & 24 \\
\hline \multirow[t]{3}{*}{ fulltime equiv. } & overall & 11.1819 & 1.28751 & 8.0277 & 15.0776 & $N=$ & 432 \\
\hline & between & & 1.27895 & 9.504338 & 13.9985 & $\mathrm{n}=$ & 18 \\
\hline & within & & 0.33057 & 9.069903 & 12.261 & $\mathrm{~T}=$ & 24 \\
\hline \multirow[t]{3}{*}{ GovRD } & overall & 8.87129 & 1.46801 & 0.8893 & 12.6645 & $N=$ & 432 \\
\hline & between & & 1.36104 & 6.524971 & 11.1732 & $\mathrm{n}=$ & 18 \\
\hline & within & & 0.63364 & 0.8523 & 10.6224 & $\mathrm{~T}=$ & 24 \\
\hline \multirow[t]{3}{*}{ fullRD } & overall & 8.68602 & 1.43746 & 5.1006 & 12.7193 & $N=$ & 432 \\
\hline & between & & 1.35976 & 6.2298 & 10.966 & $\mathrm{n}=$ & 18 \\
\hline & within & & 0.56216 & 4.847091 & 10.764 & $\mathrm{~T}=$ & 24 \\
\hline \multirow[t]{3}{*}{ water quality } & overall & 4.59175 & 0.0543 & 4.2008 & 4.6126 & $N=$ & 432 \\
\hline & between & & 0.04949 & 4.394117 & 4.6052 & $\mathrm{n}=$ & 18 \\
\hline & within & & 0.0251 & 4.398436 & 4.75424 & $\mathrm{~T}=$ & 24 \\
\hline \multirow[t]{3}{*}{ Collaboration } & overall & 3.31463 & 1.44746 & 0 & 6.7158 & $N=$ & 432 \\
\hline & between & & 1.20629 & 1.481488 & 5.77768 & $\mathrm{n}=$ & 18 \\
\hline & within & & 0.84715 & 0.649679 & 5.34348 & $\mathrm{~T}=$ & 24 \\
\hline \multirow[t]{3}{*}{ emnox } & overall & 6.19503 & 1.22012 & 4.544 & 9.9843 & $N=$ & 432 \\
\hline & between & & 1.24704 & 4.712967 & 9.58213 & $\mathrm{n}=$ & 18 \\
\hline & within & & 0.12869 & 5.769897 & 6.6066 & $\mathrm{~T}=$ & 24 \\
\hline \multirow[t]{3}{*}{ emso2 } & overall & 6.19503 & 1.22012 & 4.544 & 9.9843 & $N=$ & 432 \\
\hline & between & & 1.24704 & 4.712967 & 9.58213 & $\mathrm{n}=$ & 18 \\
\hline & within & & 0.12869 & 5.769897 & 6.6066 & $\mathrm{~T}=$ & 24 \\
\hline \multirow[t]{3}{*}{ emmvoc } & overall & 6.28927 & 1.33168 & 4.022 & 10.0464 & $N=$ & 432 \\
\hline & between & & 1.34927 & 4.37915 & 9.8301 & $\mathrm{n}=$ & 18 \\
\hline & within & & 0.2236 & 5.777836 & 6.95274 & $\mathrm{~T}=$ & 24 \\
\hline \multirow[t]{3}{*}{ IPrights } & overall & 0.55556 & 0.49748 & 0 & 1 & $N=$ & 432 \\
\hline & between & & 0.51131 & 0 & 1 & $\mathrm{n}=$ & 18 \\
\hline & within & & 0 & 0.555556 & 0.55556 & $T=$ & 24 \\
\hline \multirow[t]{3}{*}{ water dependency } & overall & 0.33333 & 0.47195 & 0 & 1 & $N=$ & 432 \\
\hline & between & & 0.48507 & 0 & 1 & $\mathrm{n}=$ & 18 \\
\hline & within & & 0 & 0.333333 & 0.33333 & $\mathrm{~T}=$ & 24 \\
\hline
\end{tabular}


The analysis of the NIC in the water sector needs to take into account those elements that impact the overall national innovative capacity, since the water innovation system can be considered a sub-system of the national innovation system. Additionally, an analysis of NIC in the water sector needs to incorporate specific elements that impact water innovations. The first step is therefore to analyze the evolution of these important indicators over time in order to identify differences between Europe and China that may lead to different levels of water innovative capacity. The second step of the analysis can then be used to verify the relation between the level of water innovative capacity with the evolution of indicators related to common innovation infrastructure, the cluster-specific environment and the quality of the linkages. Finally, the third step identifies how the interaction between these indicators may impact the overall level of the water innovative capacity.

\subsection{Descriptive data analysis}

The complexity involved in the process of technologic development goes beyond the technology itself to the whole system of technological development involved in this process (Geels, 2004, 2002; Kemp and Arundel, 1998). Understanding the systemic aspect essential to understand the development of ecoinnovation. The many actors involved in the technological development process have different skills essential for innovative activities, since the agents do not innovate in isolation, but do so in a context of a system of networks made of direct and indirect relationships (Freeman, 1995; Lundvall, 1992, 2007; Nelson, 2006). The most fundamental indicator to measure the levels of innovative activities per output are patents. A higher level of patenting per capita means a region has developed the ability to increase the development of water eco innovation, ensuring a sustainable path.

Figure 1 expresses the most basic form of innovative output: the evolution of water patents per capita and the evolution of water patents. Figure $1 \mathrm{~A}$ and $\mathrm{B}$ indicates that the overall level of patenting activities in China is increasing but at a much lower level than Europe. The European national innovative capacity presents a 
infrastructural characteristics of the water sector. Figure $1 \mathrm{C}$ shows patenting per capita in Europe and China;

it is clear that the overall level of patenting activities is significantly lower in China. Figure 1D shows the patenting in Europe, the average for European countries and China where it can be seen that, despite the fact that patenting activities in China are at a much lower level compared to Europe, it is at a similar level with respect to the European average. The analysis of the evolution of the innovative output per se is not enough to understand why there are different levels of innovative capacity. The different levels of variables such as the regulatory framework, investments, and other elements related to the common innovation framework may increase or hamper the innovative capacity.

(a)

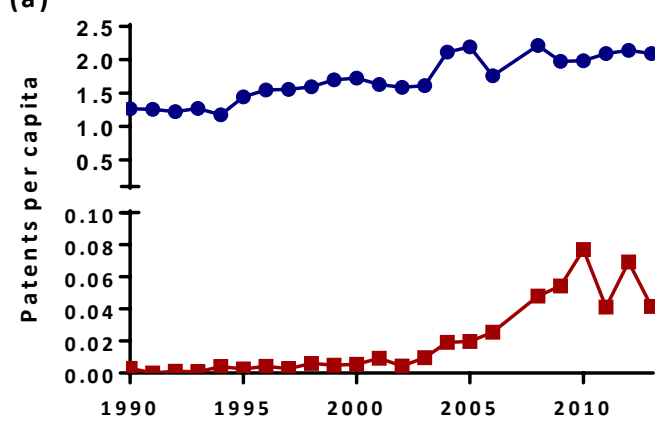

(c)

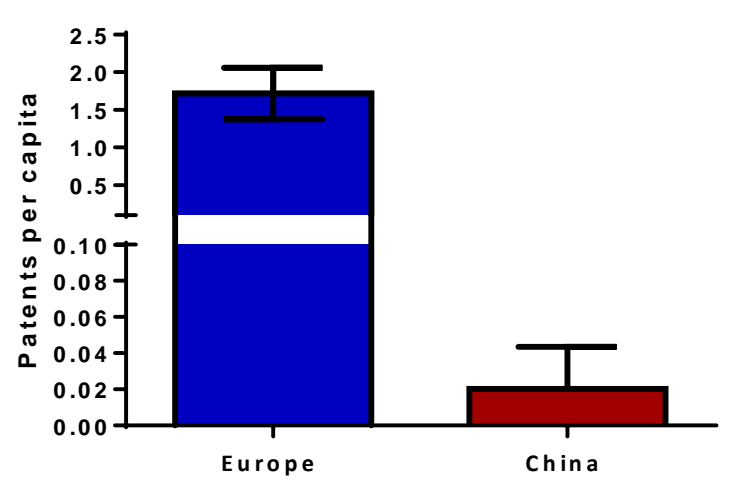

(b)

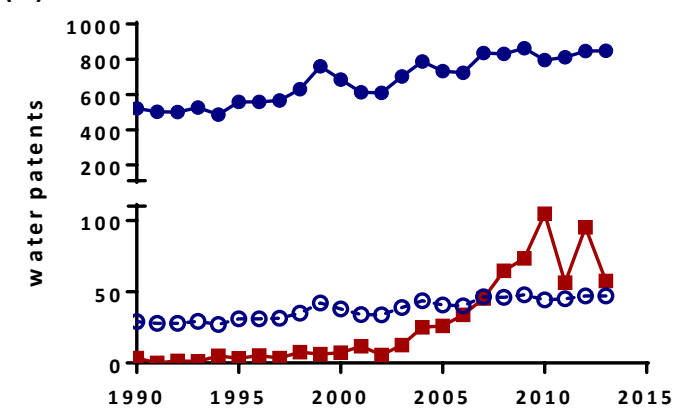

(d)

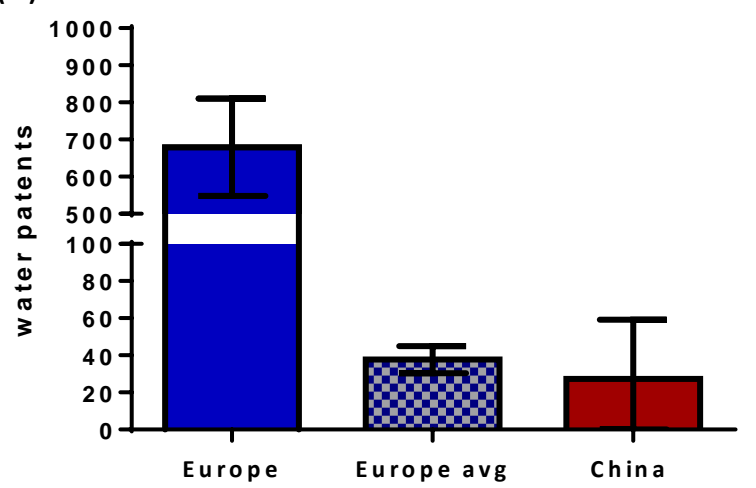

Figure 1: Evolution of the measures for innovative output in (A) water patents per capita and (B) water patents for

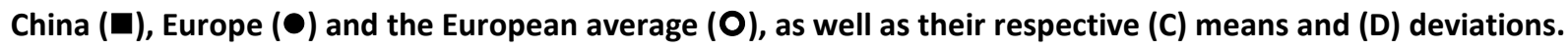

Some of the most important investments and policy choices that support innovative activity have broad impact throughout an economy-these are the common innovation infrastructures. The differences in common innovation structure can therefore provide information regarding the different levels of innovative 
capacity between the two regions. The water sector is highly regulated with a mix of private and public actors involved in the process of knowledge creation. These actors in turn are influenced by the government directions in terms of regulatory frameworks, budget levels and overall public involvement. The amount of money invested in R\&D is also a reflection of the innovation input performed by a country.

Figure 2 provides an overview for selected elements from the common innovation infrastructure and its evolution over time. Figure $2 \mathrm{~A}$ shows that Europe and China have been improving the ability of their environmental regulations to drive innovations; China was lagging behind but it clearly changes from around 2011 when stronger water regulations were established as they recognized the need to shift towards a more sustainable path. In contrast, for Europe a fairly continuous growth can be seen underlining the region's position as a first mover into the green economy agenda. In any case, this result highlights that both regions are using regulations to drive eco-innovation. Figure $2 \mathrm{~B}$ shows the collaboration index, which indicates the level of patenting collaboration with other countries for each region. This indicator is comparable in Europe and China until around 2000, at which point a substantial increase in the collaboration index for China is suggestive that they had adopted a strategy of learning-by-interacting and trying to assimilate external knowledge. In Figure 2C, the evolution of China with respect to Europe can be seen where both regions present positive growth with respect to direct investments (as \% GDP), but the direct investment in Europe is consistently at a higher level than in China. Finally, Figure 2D presents the evolution of total R\&D expenditure where Europe presents a consistent and strong investment in R\&D, and China starts at a lower level but catches-up with Europe showing a transition from a low level of investments to a high level of investments that may reflect changes on the national innovative capacity in the water sector. 
(a)

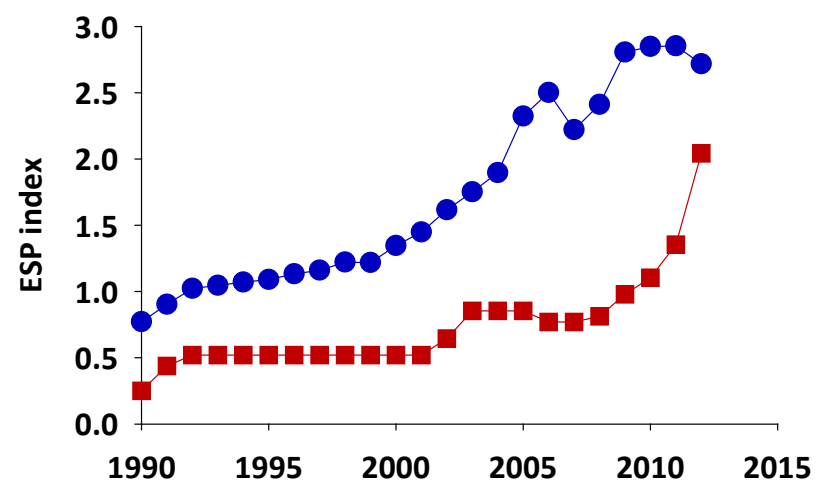

(c)

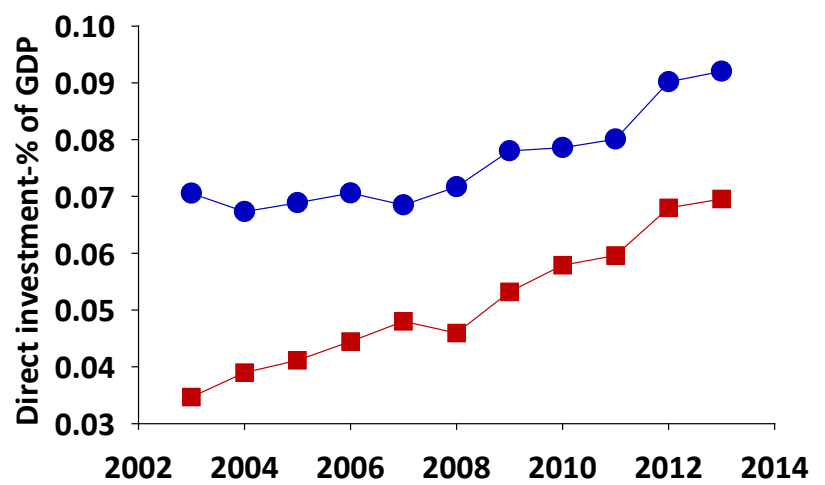

(b)

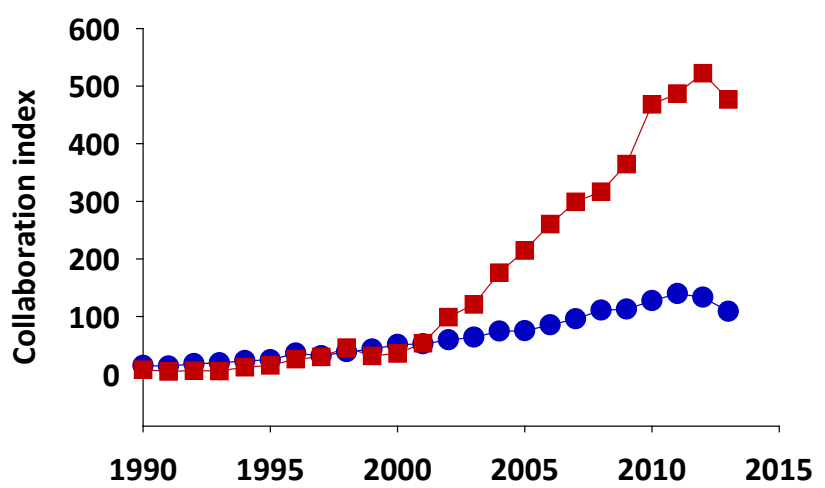

(d)

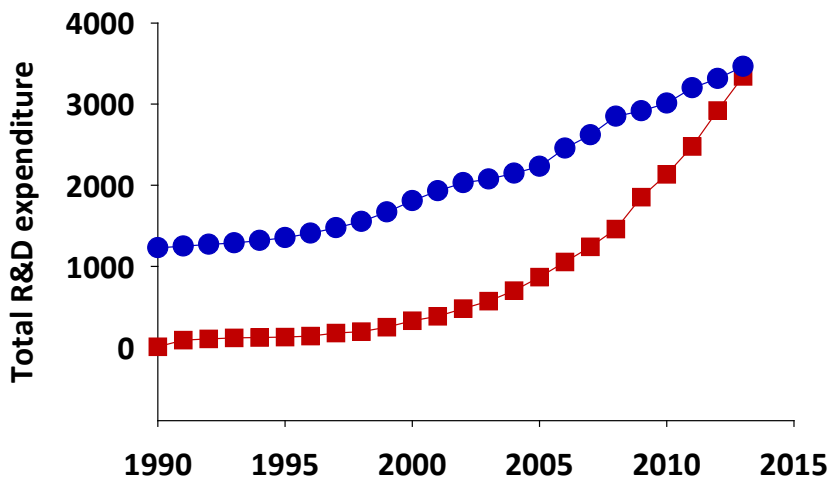

Figure 2: Evolution of the common innovation infrastructure in China ( $\square$ ) and Europe $(\bullet)$ for the (A) evolution of the environmental stringency policy index (ESP); (B) evolution of the collaboration in patenting activities index; (C) evolution of the direct investments (as \% of GDP); and (D) evolution of the aggregate R\&D expenditures.

Figure 3 provides an overview of other selected elements from the common innovation infrastructure. Figure 3A presents the evolution of the GDP per capita, where it can be observed that the level of GDP per capita in China is lower compared to Europe, indicating the different stages of development in each of these two regions. Figure 3B shows the evolution of the water patent stock which is constantly increasing in Europe, but is almost constant for China indicating their lack of innovative activities within the water sector. This result also highlights the European position, specifically as one of the innovative leaders in this (OECD, 2014). Figure $3 \mathrm{C}$ shows the evolution of full-time equivalents (i.e. aggregated employment in science and technology) where a fast evolution can be seen for China, reaching and then surpassing European levels from 2010 moving forwards. Figure 3D shows the remarkable evolution on investments in higher education in China, which is indicative for a structural change with respect to education. These results taken together show that China is changing substantially over time compared to Europe, which is expected since the country 

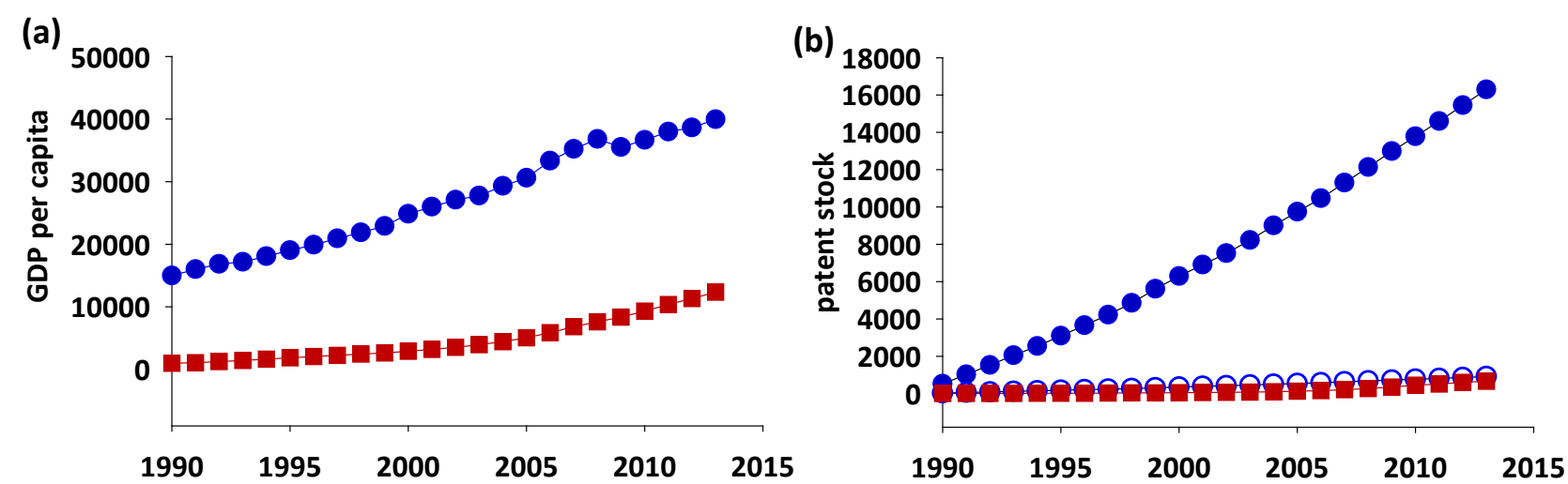

(d)

(c)

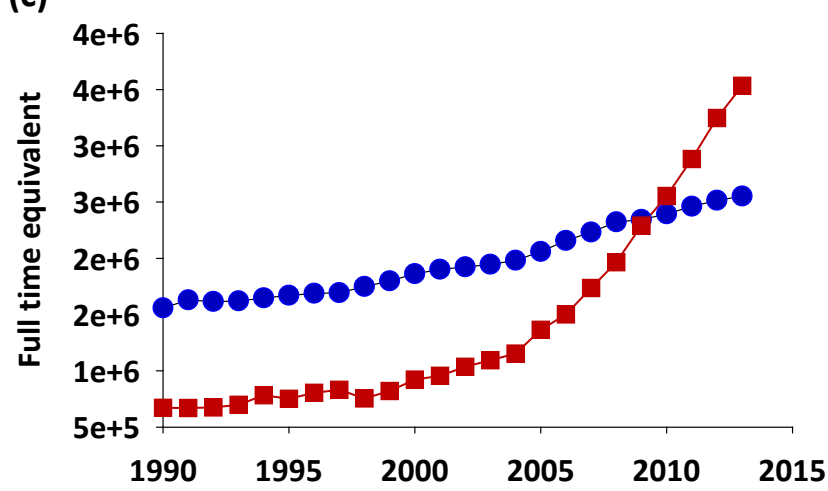

Figure 3: Evolution of the common innovation infrastructure in China $(\square)$ and Europe ( $O)$, including the $(A)$ evolution of the GDP per capita; (B) evolution of the water patent stock; (C) evolution of full-time equivalents; and (D) evolution of the investment in higher education.

However, the common innovation structure alone doesn't determine the level of innovative capacity of a nation. The interaction among the actors in the innovation system can have a high impact on the level of innovative activities. For example, the water sector relies on public investments and the development of research from universities and companies. Therefore, the composition of public/private R\&D expenditure has been analyzed to evaluate the evolution of the elements related to cluster-specific environments (Figure 4). Figure 4A shows the evolution of the water specialization index, where it can be seen that the 
level in Europe and China does not exhibit large fluctuations over time and that China's index is slightly

(b)

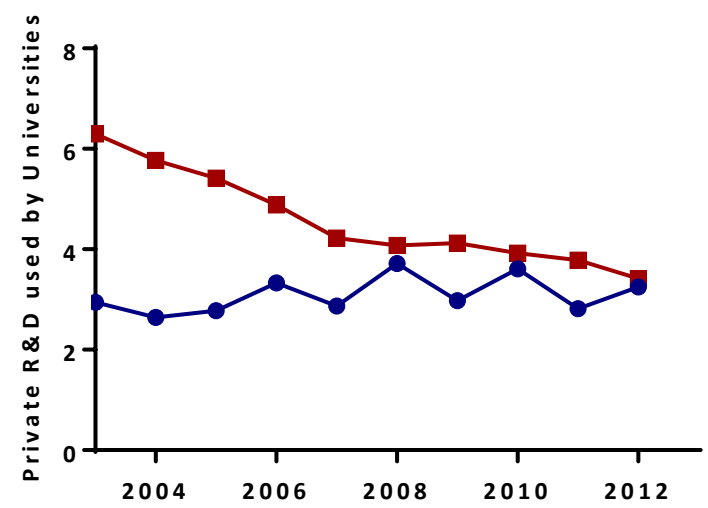

(d)

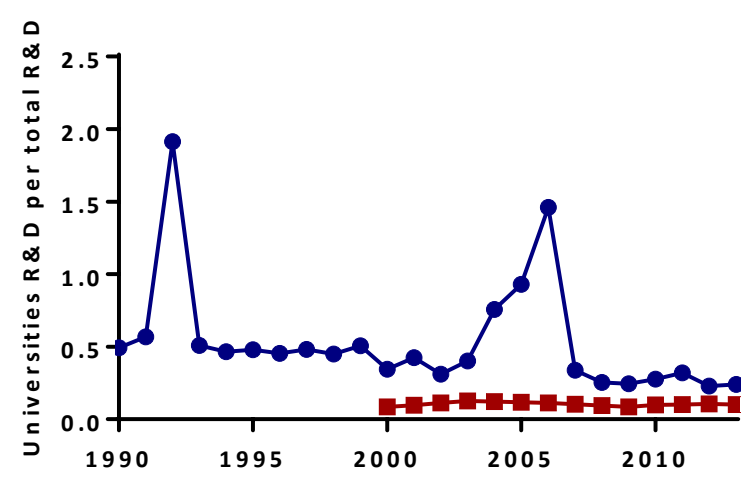

Figure 4: The evolution of the cluster-specific environment in China $(\square)$ and Europe $(\bullet)$, including the $(A)$ evolution of the water specialization index; $(B)$ evolution of the private $R \& D$ performed by universities; $(C)$ evolution of the private $R \& D$ investments as a percentage of all $R \& D$; and (D) evolution of $R \& D$ performed by universities per total $R \& D$ performed.

The overall evolution of the main indicators related to NIC reflect the different stages of development for the selected regions: China presents an ongoing change to its innovation system structure, where, in this 
stage, the role of the government tends to be stronger in guiding and influencing these changes (Gu and Lundvall, 2006; Hu and Mathews, 2008). In contrast, Europe presents a more stable evolution of its indicators showing an innovation system that is more mature and structured. These results may give an indication for the evolution (and stage) for the main (aggregated) indicators related to water innovative capacity, but they do not provide information related to any potential relationships existing between them and the selected output for water innovative capacity (i.e. water patents per capita and water patents). The following section therefore evaluates the relationships that may exist among the selected indicators at the level of the national innovative capacity. Porter and Linde, 1995) and may also be the case for eco-innovations in the water sector, therefore the ESP index is tested on the partial regressions. Other factors might be equally or more important to explain the development of eco-innovation, some of which may also be sector-specific, including the role of differences

\subsection{Partial regressions analysis}

The relationship among the framework conditions and the interaction among actors can lead to a high or low innovative capacity. The ability of a country to succeed in the development of innovation can reflect its position in the global value chain. In order to analyze the relationship of patenting activities and selected indicators from the framework conditions and the relationship among companies and universities, we used partial regression for the main indicators that according to the literature might affect the water innovative capacity more than the other tested indicator from Furman et. al. (2002) The ability for environmental regulations to drive eco-innovation is widely known in the literature see: (Horbach et al., 2017; Kemp, 2010; and similarities in technological regimes, sectoral institutions, demand, and market structures (Oltra, 2008) as well as the ability to interact in order to create knowledge (Lundvall, 2007). In this context, the level of the collaboration index states the learning by interacting activities, in a globalized world, can be a proxy for the level of interaction.

The partial regression results show that both China and Europe's water patenting activities respond to a positive increase in the level of the ESP index, suggesting that regulations positively impacts the level of 
441 innovative capacity as shown in Figure 5. The same trend is also observed for the collaboration index, where 442 a positive change in the level of collaboration also positively impacts the level of water patenting activities 443 see table 2. This result shows that a countries national innovative capacity in water can benefit from stronger 444 water policies and high level of collaboration. These results are expected and extensively discussed in the 445 literature of NIC, but we now confirm that the water sector follows the same trend. Moro et al. (2018) stated 446 that the level of patenting activities follows the evolution on water policy and regulations, indicating that 447 China is incorporating aspects of the green agenda in their development strategy, with the water sector being 448 one of the prioritized sectors to benefit from the governmental investments.
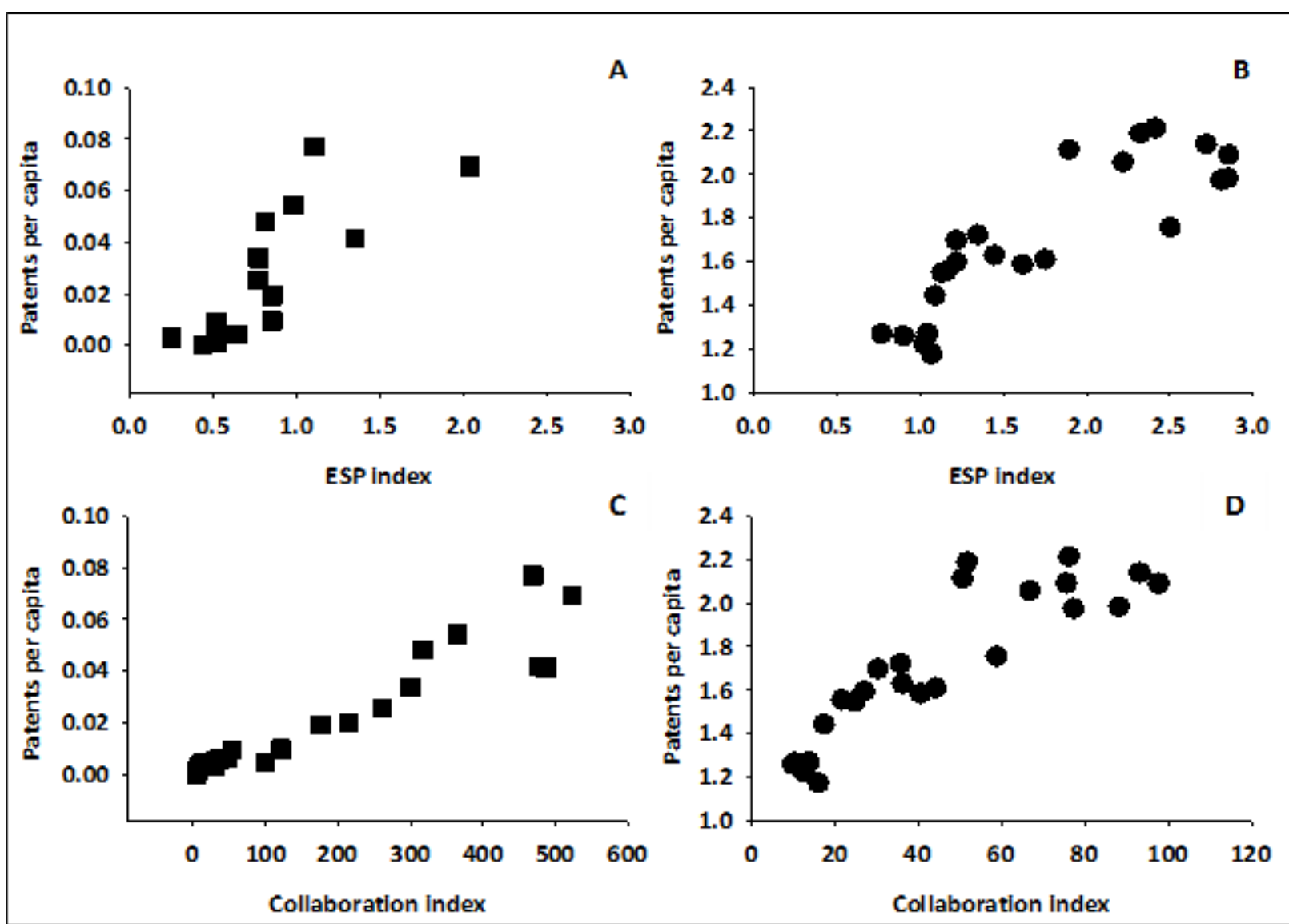

450 Figure 5: Evolution of water patents per capita in Europe $(\bullet)$ and China $(\square)$ as a function of the ESP index (A;B) and 451 as a function of international collaboration index (A;D).

Table 2 presents the results from the partial regressions. The results show that both indicators (ESP and 454 collaboration indices) positively affect the level of water patents per capita. The ESP index has a greater 
455 importance for Europe than for China, suggesting that regulations may be one of the reasons why these two 456 regions display different water innovative capacity levels. In contrast, the level of collaboration presented a 457 similar magnitude in both regions. This suggests that, despite the high level of collaboration in China 458 compared to Europe, the latter still presents higher innovative levels (see Fig. 1). This results shows that other 459 variables might be more important for determining the innovative capacity in the water sector, or that the 460 isolated effect of the collaboration might not be enough to increase the innovative capacity in this sector, 461 since the innovative levels in Europe are higher than in China despite the fact that China presents higher 462 levels of collaborations (level of shared water patents of a country). An alternative explanation might be that 463 the indicator reflective of collaboration may not necessarily reflect interactive learning, but it can also be 464 related more to an "imitation" mode of innovation from the Chinese side, that relies on foreigner knowledge 465 rather than to develop internal capabilities to perform innovation. In any case, the analysis should be 466 expanded, including other variables, besides regulations and collaborations.

467 Table 2: Summary regression statistics linear regressions results (I).

\begin{tabular}{lcccc}
\hline Independent Variable & \multicolumn{4}{c}{ Dependent variable: water patent per capita } \\
\cline { 2 - 5 } ESP index & China & Europe & China & Europe \\
& 0.0505 & 0.411 & & \\
Collaboration index & $(0.00774)$ & $(0.0524)$ & & 0.00744 \\
& & & 0.00743 & $(0.000822)$ \\
$\mathbf{R}^{2}$ & & & $(0.00102)$ & \\
\hline
\end{tabular}

Figure $6 \mathrm{~A}$ and $\mathrm{B}$ displays the evolution of water patenting activities in China and Europe as a function of 470 the government direct investments, as well as a function of aggregate investment in R\&D (Figs.C; D). The 471 direct investment results showed no significance for Europe, which may reflect a different stage of development (see table 3). The results show that water patenting activities also respond positively to an increase in total $R \& D$, where the positive effect of $R \& D$ on water patenting activities was expected. 
(a)

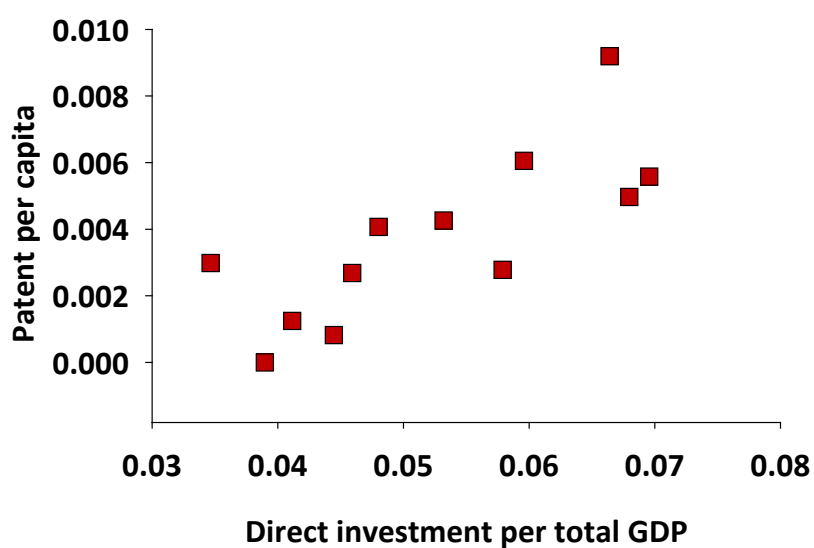

(c)

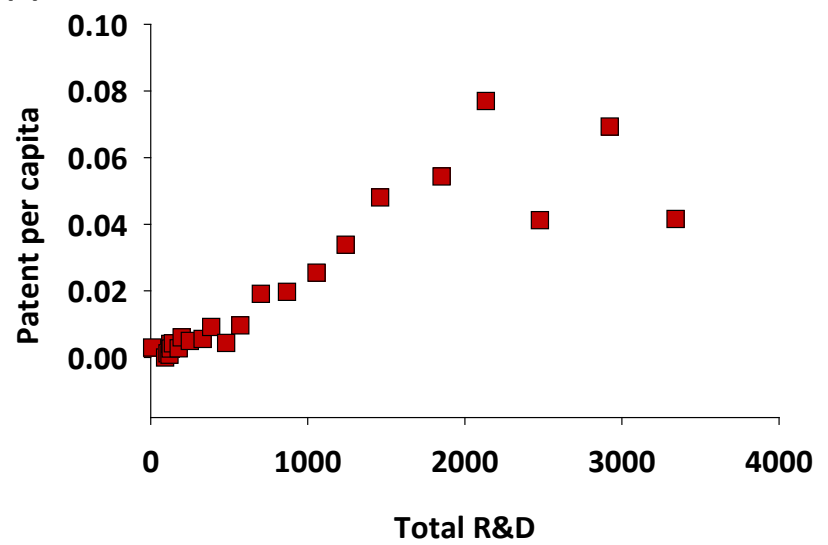

(b)

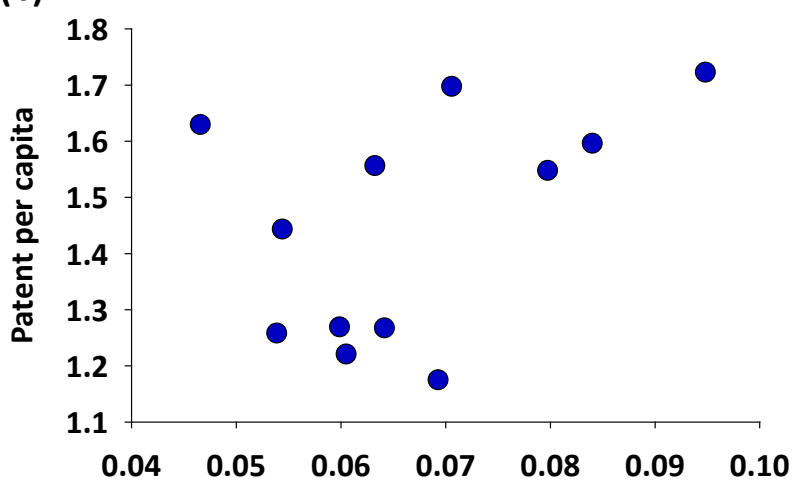

(d)

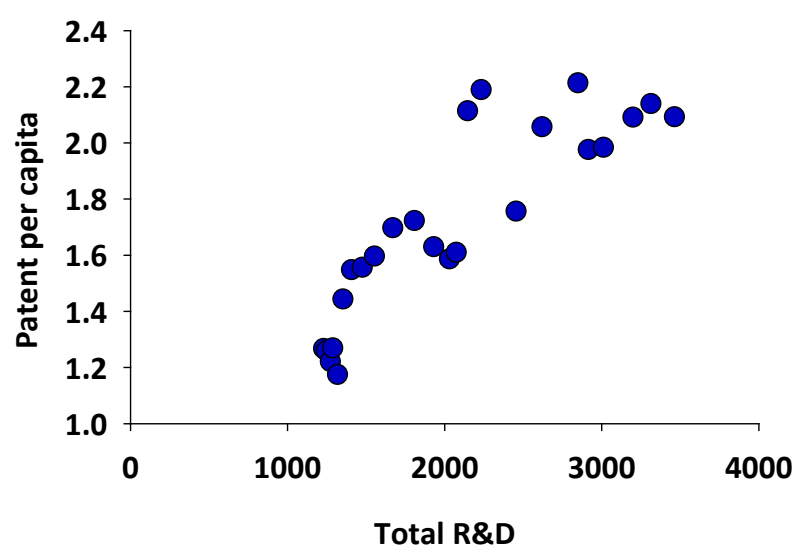

474

475 

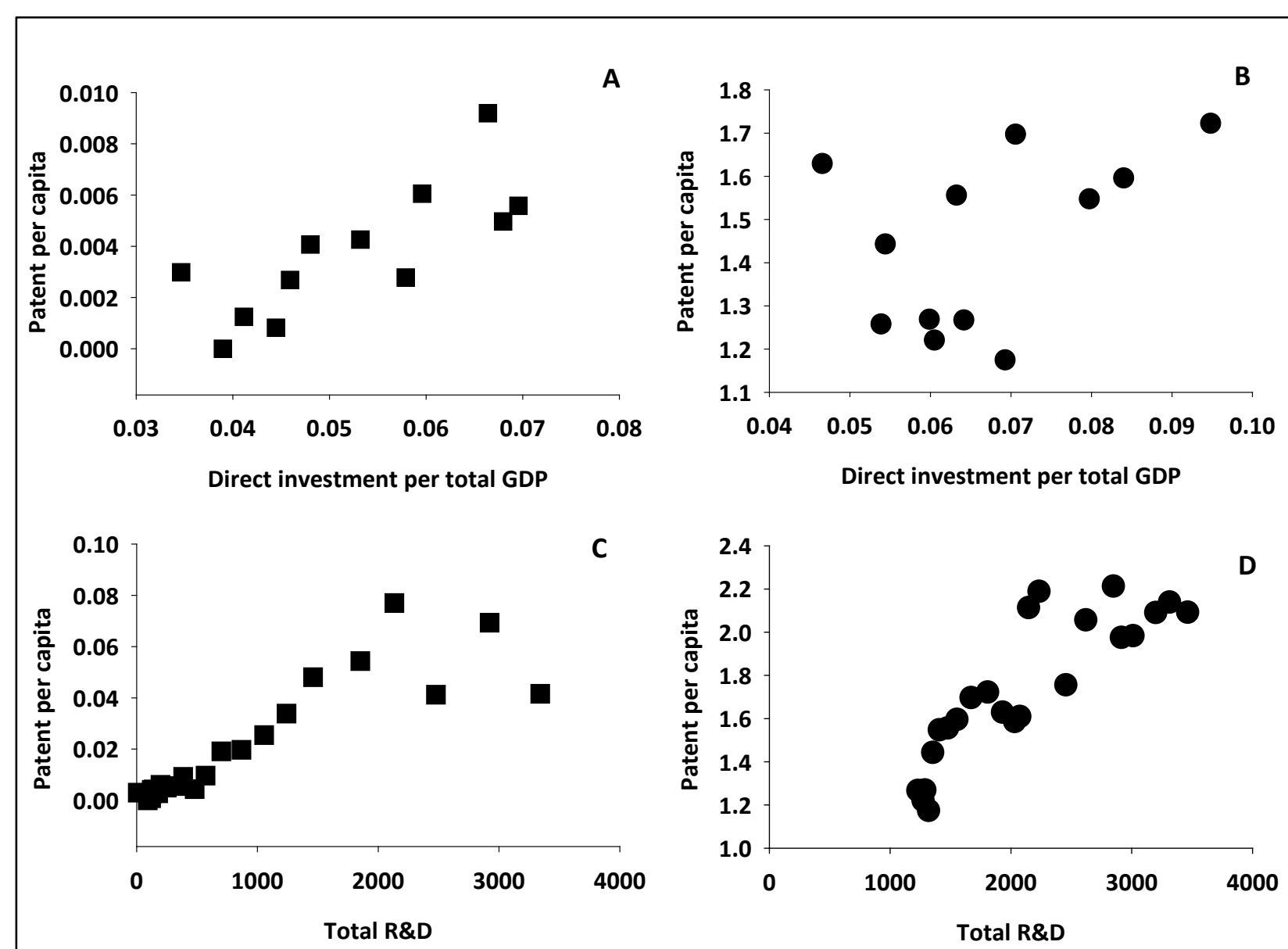

Figure 6: Evolution of international collaboration index over time (1990-2013) in China(口) A Europe (0) B and Evolution of water patents per capita as a function of the level of international cooperation in patenting activities in China(ロ) C; Europe (O) D.

In Europe, the water patenting activities did not display a significant relationship with the direct investments, as the partial regressions was not significant, whereas in China the direct investment has a positive impact on the level of water patenting activities (Table 3). This result indicates that the role played by government is more important in China than in Europe for driving water innovation. This finding is in line with $\mathrm{Hu}$ and Mathews (2008b, 2005) which states that developing countries have different national innovation system characteristics compared to developed countries, meaning that the role of government is more important for overcoming barriers for their national innovation system development, in the water sector the governance problems have been pointed out as barrier for further technological development (De Montalvo and Alaerts, 2013) In this context the paper uses the role of direct government investment as a proxy for governance, the indicator may not be the best fit to reflect the positive impact of good water 
governance, but nevertheless, it reflects the basic structural differences between Europe and China, where the government has a bigger role on promoting investments and innovations.

Table 3: Summary regression statistics linear regressions results (II).

\begin{tabular}{lcccc}
\hline Independent Variable & \multicolumn{4}{c}{ Dependent variable: water patent per capita } \\
\cline { 2 - 5 } Direct investment & China & Europe & China & Europe \\
& 1.371 & $*$ & & \\
Total R\&D & $(0.406)$ & & 0.000224 & 0.00649 \\
& & & $(0.0000238)$ & $(0.000709)$ \\
$\mathbf{R}^{\mathbf{2}}$ & & - & 0.792 & 0.783 \\
\hline
\end{tabular}

$*$ = Not significant

The framework conditions provide the general environment for technological development, but the cluster-specific environment reflects the micro-environment where the actual innovation process takes place. Therefore, the water national innovation system relies on the good interaction of the actors involved in the process of water innovation creation and diffusion to improve the water innovative capacity. This micro-environment is too complex to be properly analysed due to a lack of quantitative data in the water sector that could enable an international comparison. Instead, this paper focuses on aspects of the R\&D development in order to preliminarily analyse the cluster-specific environment and the quality of the linkages.

Figure $7 A$ and $B$ presents the percentage of private $R \& D$ as total $R \& D$, which reflects the level of entrepreneurship in a country. Figures $7 C$ and $D$ present the level of private R\&D performed by universities, which shows the level of interaction between private and public innovators. The results show that these indicators have no significance for Europe, but they present ambiguous results for China (see Table 4). The private $R \& D$ has a positive effect on the patenting activities in China, whereas the private R\&D performed by universities has a negative impact on the level of water patenting activities. This suggests that in order to reach a higher level of water innovative capacity, the private innovators have to play a major role in the development of water innovations in China. The negative impact of private R\&D performed by universities is relatively small (0.0099), suggesting that changes on the level of private R\&D performed by universities has 
little impact on the level of innovative capacity. This is an unexpected result, since the private R\&D performed by universities is a proxy for the quality of interaction among companies and universities, and the importance

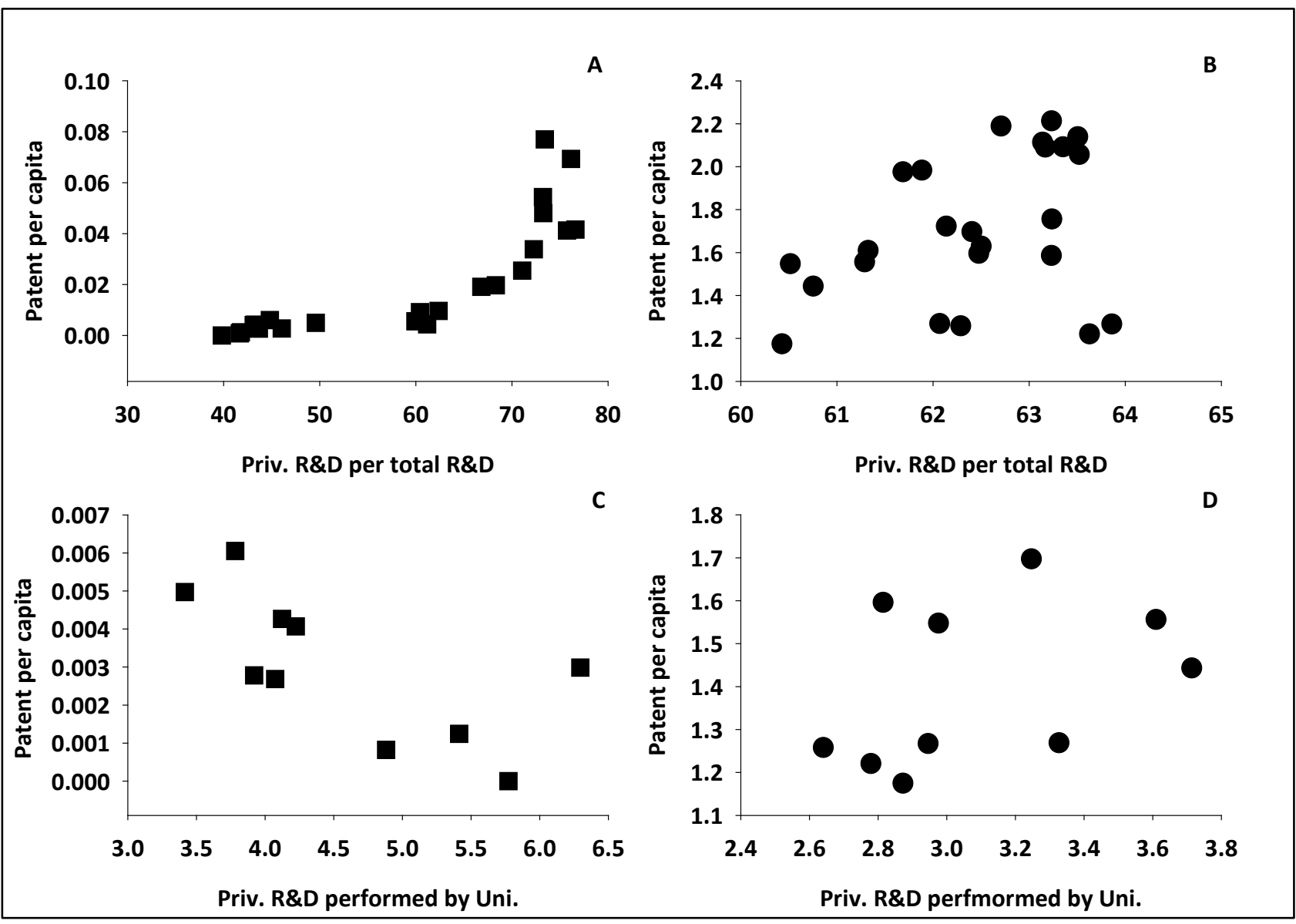

Figure 7: Evolution of water patents per capita as a function of (A) total R\&D and (B) private R\&D investments performed by universities for China( $\square)$ and Europe (๑).

Table 4: Summary regression statistics linear regressions results (III).

\begin{tabular}{|c|c|c|c|c|}
\hline \multirow[t]{2}{*}{ Independent Variable } & \multicolumn{4}{|c|}{ Dependent variable: water patent per capita } \\
\hline & China & Europe & China & Europe \\
\hline Priv. R\&D & $\begin{array}{c}0.00140 \\
(0.000214)\end{array}$ & $*$ & & \\
\hline Priv.R\&D Uni & & & $\begin{array}{c}-0.00990 \\
(0.00159)\end{array}$ & $*$ \\
\hline $\mathbf{R}^{2}$ & 0.510 & - & 0.807 & - \\
\hline
\end{tabular}



capacity in Europe and China, where particularly the direct role of the government is more relevant in China than in Europe. Environmental regulations, as a driver for eco-innovation, is dominant in both regions. This indicator reflects both the indirect influence of the government, reducing uncertainties related to which technological trajectory should be followed and offering incentives to adopt a sustainable path, as well as the direct influence (direct government investment) related to the role a government plays in providing funds for investing in water-related innovation activities. Clearly differences exist regarding government "strategies" in both regions where the Chinese government has a more straightforward approach, i.e. investment in infrastructure, such as railways, energy infrastructure and water infrastructure. The next section provides an analysis of how the combinations of these elements affect the water innovative capacity.

\subsection{Water innovative capacity analysis}

The combination of the different elements on the framework conditions, the level and nature of interaction among innovative actors and their relation with the innovation environment can influence the innovative capacity. Countries that developed the ability to promote efficient regulations often lead to a higher level of eco-innovation development (Andersen, 2004; Horbach et al., 2011; Kemp and Pontoglio, 2011). Besides regulations, the propensity of a country to interact with others to generate new knowledge may also lead to 538 higher levels of innovative capacity (Gregersen and Johnson, 1997). The amount of government expenditure 539 is also related to higher levels of innovative capacity, the more investments on R\&D higher are the changes 540 to increase the technological development. The argument in this paper, therefore, is that water innovative capacity is intrinsically related to a country's national innovative capacity due to the fact that the investments and evolution of the sector will follow the evolution and stage of development of the nation; the demand and investments in the sector will also follow those trends to a certain degree. 
Table 5 presents the results of the summary regression ${ }^{4}$ statistics using water patents as the dependent variable. The overall results show that the GDP per capita doesn't have a correlation with the level of national innovative capacity, a result which partially differs from OECD (2016) which states that rich countries will have the means to develop water innovations, whereas poorer countries cannot thereby creating a "northsouth" market of water technologies. Importantly, this result shows that the level of GDP itself does not reflect an advantage on the development of water technologies, such that other elements should be taken into account. Furthermore, the water regulations present a positive impact on the level of water innovative capacity, a result which is again in line with the literature discussing environmental regulations as drivers for 552 eco-innovation (Eco-Innovation Observatory (EIO), 2016; Li, 2009; Porter and Linde, 1995).

553 Table 5: Summary regression statistics for panel data, linear regression (I), random effects (II), fixed effects (III).

\begin{tabular}{|c|c|c|c|c|c|c|}
\hline \multicolumn{7}{|c|}{ Dependent Variable: Water patents } \\
\hline Variable/ Model & 1-(I) & 1-(II) & 1-(III) & $2-(1)$ & 2-(II) & 2-(III) \\
\hline \multirow[t]{2}{*}{ ESP index } & 0.1839922 & 0.2377456 & 0.2441214 & $*$ & 0.2130214 & 0.2196979 \\
\hline & $(0.914417)$ & $(0.1018744)$ & $(0.1040255)$ & & $(0.0983315)$ & $(0.1019533)$ \\
\hline \multirow[t]{2}{*}{ Population } & $*$ & $*$ & & 0.5036978 & 0.624628 & $*$ \\
\hline & & & & $(0.0553652)$ & $(0.0805713)$ & \\
\hline \multirow[t]{2}{*}{ PrivRDUni } & -0.0478009 & $*$ & $*$ & -0.0543254 & * & $*$ \\
\hline & $(0.0191503)$ & & & $(0.0189194)$ & & \\
\hline \multirow[t]{2}{*}{ Water quality } & 11.48144 & 7.583321 & 6.507264 & 11.89321 & 8.508264 & 7.840374 \\
\hline & $(1.222003)$ & $(1.732189)$ & (1.684098) & $(1.114567)$ & $(1.243553)$ & $(1.29764)$ \\
\hline \multirow[t]{2}{*}{ Collaboration } & 0.4227477 & 0.1837857 & 0.1484677 & 0.377241 & 0.1637871 & 0.1332878 \\
\hline & (0.0557899) & $(0.0708037)$ & $(0.0573136)$ & $(0.0531431)$ & $(0.0520746)$ & $(0.0561764)$ \\
\hline GDP capita & $*$ & $*$ & $*$ & $*$ & $*$ & $*$ \\
\hline \multirow[t]{2}{*}{ IpRights } & 1.127842 & 1.308016 & $*$ & 1.240217 & 1.43248 & \\
\hline & (0.1009794) & $(0.3102294)$ & & $(0.0821995)$ & (0.174973) & \\
\hline
\end{tabular}

\footnotetext{
${ }^{4} \mathrm{~A}$ "dummy" was used for China in order to capture their effects and also the control for years, both didn't present significance on the model, suggesting that the overall elements that impacts the level of water innovative capacity are similar in both regions, the lack of significance on the control for the years suggests that the elements that impact the water innovative capacity didn't change over the last 20 years.
} 


\begin{tabular}{|c|c|c|c|c|c|c|}
\hline Water & -0.3047857 & $*$ & $*$ & -0.3493336 & $*$ & \\
\hline dependency & $(0.0984026)$ & & & $(0.0750098)$ & & \\
\hline \multirow[t]{2}{*}{ emnox } & -0.0743148 & $*$ & $*$ & & & \\
\hline & $(0.178652)$ & & & & & \\
\hline Emso2 & & $*$ & $*$ & & & \\
\hline \multirow[t]{2}{*}{ emmvoc } & 0.212037 & $*$ & $*$ & & & \\
\hline & $(0.0776557)$ & & & & & \\
\hline \multirow[t]{2}{*}{ Constant } & -52.33118 & -38.77396 & -34.55679 & -54.06323 & 41.62003 & -38.7604 \\
\hline & $(4.873448)$ & (6.169259) & (7.298714) & (4.589805) & (4.910751) & (6.237679) \\
\hline $\mathbf{R}^{2}$ & 0.81 & 0.80 & 0.56 & 0.81 & 0.80 & 0.48 \\
\hline
\end{tabular}

The water quality indicators (drinking water coverage as a proxy) display a positive impact on the overall 556 level of water innovative capacity. This result reflects the focus given to developing water-infrastructure and 557 the level of the country's development, indicative that the innovative capacity increases along with the 558 development of water infrastructure which is related to the stage of development for a given economy. 559 Water quality is furthermore related to the stage of the country's development, mainly suggesting that richer 560 countries have more money to spend on infrastructure which will affect their water innovative capacity. This 561 result is again in line with the discussion about the level of innovations in the water sector being linked with 562 local budgets which may suffer fluctuations from external instabilities (European Commission, 2016).

563 The level of IP-rights also displays a positive effect on the level of water innovative capacity, additionally 564 reflecting the innovation environment and infrastrucutre of a country. The collaboration index also presented 565 a positive impact on the water innovative capacity, showing that higher levels of knowledge interaction and 566 creation can lead to a higher innovative capacity. This result reflects, to a certain degree, the Chinese strategy 567 for choosing to interact with the international community to accumulate knowledge. The population level 568 has a positive impact on the water innovative capacity, where this result can be understood in two ways: on 569 the one hand it reflects more labour force, and on the other, it indicates the (potential) increase in pressure 
570 (demand) for (decreasing) available water resources, thus leading a country to look for smarter sollutions for 571 their water resources management.

572 The second set of regression uses water patents per capita as a dependent variable. Table 6 presents 573 the results from the summary regression statistics for the panel data, linear regression (I), random effects 574 (II), and fixed effects (III) using water patents as a dependent variable.

575 Table 6: Summary regression statistics for panel data, linear regression (I), random effects (II), and fixed effects (III).

\begin{tabular}{|c|c|c|c|c|c|c|}
\hline \multicolumn{7}{|c|}{ Dependent Variable: Water patent per capita } \\
\hline Variable/ Model & 1-(I) & 1-(II) & 1-(III) & 2-(I) & 2-(II) & 2-(III) \\
\hline \multirow[t]{2}{*}{ ESP index } & 1.355904 & 0.2069292 & 0.1860151 & 1.482451 & 0.5034895 & 0.4769381 \\
\hline & $(0.1279181)$ & $(0.0159246)$ & $(0.0704305)$ & $(0.1201043)$ & $(0.0683097)$ & $(0.0680526)$ \\
\hline \multirow[t]{2}{*}{ PrivRDUni } & 0.1349525 & 0.0581606 & 0.0569154 & 1187504 & 0.0661487 & -0.0274403 \\
\hline & $(0.0377718)$ & $(0.0159246)$ & 0.0157703 & (0.0389078) & (0.0198169) & (0.0306691) \\
\hline \multirow[t]{2}{*}{ Collaboration } & 0.1395332 & 0.3887867 & 0.3980715 & & & \\
\hline & $(0.0552231)$ & $(0.0413189)$ & $(0.0414419)$ & & & \\
\hline Specialization & 5199135 & 0.5899158 & 0.5907831 & & & \\
\hline Index & $(0.0797084)$ & $(0.0857986)$ & $(0.0436408)$ & & & \\
\hline Uni RD & $*$ & $*$ & $*$ & $*$ & $*$ & $*$ \\
\hline \multirow[t]{2}{*}{ Gov RD } & & & & -0.1228536 & 0.1822262 & 0.205288 \\
\hline & & & & $(0.0474104)$ & $(0.0519497)$ & (0.052979) \\
\hline \multirow[t]{2}{*}{ Constant } & 52.33118 & -0.0983115 & -0.0198415 & -6.197229 & -4.126341 & -4.126341 \\
\hline & $(4.873448)$ & $(0.8386192)$ & $(0.3130033)$ & $(0.6634751)$ & $(0.5254801)$ & (0.5254801) \\
\hline $\mathbf{R}^{2}$ & 0.33 & 0.20 & 0.19 & 0.27 & 0.14 & 0.12 \\
\hline
\end{tabular}

$*$ not signigicant $\mathrm{p}<0.05$

577 The regression results indicate that the specialization index presented previously had a positive effect on 578 the level of the water innovative capacity, see also Table 5. These results further indicates that regulations 579 are the prime driver for eco-innovation development (Arundel and Kemp, 2009; Porter and Linde, 1995). The 
Private R\&D performed by universities also impacts the level of water innovative capacity, showing that the higher level of interaction among the actors in the water innovation system (especially in China) positively affects the level of national water innovative capacity further indicating the importance of intra-country interactions on knowledge creation and diffusion. The collaboration index also positively affects the level of water innovative capacity suggesting that not only the intra-country interaction is important for the process of innovation development, but also international interaction can affect the level of innovative capacity.

The remarkable differences from the determinants of national innovative capacity to the water innovative capacity is related to the GDP per capita, suggesting that rich countries with a high level of innovative capacity will not necessarily also have a high level of water innovative capacity. The water innovative capacity relates with the direction of regulations, along with investments and levels of interaction among the domestic actors vis $a$ vis to the levels of interaction with international actors. Other elements, such as publications, openness and market share, presented a high level of correlation and therefore weren't integrated into the models. These results are in line with the body of evolutionary literature, which states that a successful technological development in a globalized economy is related to the level of investments and the capacity of interaction among the actors (Lundvall et al., 2002; Lundvall, 2007; Nelson, 2006). In addition, the development of water eco-innovation is not only related with stronger water regulations, but also with the level of investments and the capacity of interaction present among the actors within the innovation system. This further highlights that water eco-innovations are ultimately related to investments, which are shaped by the synergy between innovation policies and environmental regulations (Andersen and Faria, 2015; Kemp and Soete, 1992; Nill and Kemp, 2009; Porter and Linde, 1995)

\section{Conclusions}

This paper tested a set of indicators to analyse the water innovative capacity in Europe and China. Based on the work developed by Furman et al. (2002), the paper tested variables related to the common innovation structure and industrial cluster-specific environment, and developed an adapted model for water 
604 innovations. The paper additionally added the (i) environmental policy stringency index, (ii) the level of 605 international collaboration on patenting activities and (iii) water-related indicators in order to include key 606 sectoral-specific elements driving the innovative capacity in the water sector in the analysis. The challenges 607 related to this analysis goes beyond the lack of specific quantitative data for the water sector, but points 608 additionally to a literature gap regarding what drives knowledge creation and diffusion in the water sector, 609 where this paper attempts to provide a first (more qualitative) step.

610 The results showed that China has evolved its innovation infrastructure over time to levels similar to 611 Europe. There are still differences related to the role of government and the level of interaction among actors 612 when creating innovation. Notably, environmental policy and governmental R\&D were found to be crucial 613 for the development of water innovation, which was in contrast to previous results from other. The level of 614 specialization was also found to be relevant for the national innovative capacity. Overall, the results indicate 615 that China is progressing towards a higher level of water innovative capacity; however, the Chinese water 616 innovative capacity is still at a much lower level than Europe. The reason for this difference seems to be 617 related to the level of maturity of the innovation system and the stage of development across the two 618 regions. With the rising number of water challenges particularly in China, improving the water innovative 619 capacity will be crucial for sustaining economic development and growth. This paper contributes to 620 understanding the determinants of the innovative capacity in the water sector and it highlights the 621 importance of focusing on water infrastructure development, as well as the micro-environment for water 622 innovations. These results nevertheless indicate that Europe performed better than China, due to the 623 evolution of both the water infrastructure and the micro-environment. 
References

Alaerts, G.J., Kaspersma, J., 2009. Progress and challenges in knowledge and capacity development. Capacit. Dev. Improv. water Manag. 3.

Andersen, M.M., 2010a. Eco-innovation in the globalizing Learning Economy: The Greening of national Innovation systems. 8th Int. Conf. Globelics 2010 1-31.

Andersen, M.M., 2010b. On the Faces and Phases of Eco-innovation on the Dynamics of the Greening of the Economy, in: Summer Conference 2010-Opening up Innovation: Strategy, Organization and Technology. p. 24.

Andersen, M.M., 2006. Eco-innovation indicators, European Environment Agency. Copenhagen.

Andersen, M.M., 2004. An innovation system approach to eco-innovation-Aligning policy rationales, in: The Greening of Policies-Interlinkages and Policy Integration Conference. pp. 1-28.

Andersen, M.M., Faria, L.G.D., 2015. Eco-innovation Dynamics and Green Economic Change: the role of sectoral-specific patterns., in: R\&D Management Conference 2015.

Archibugi, D., 1992. Patenting as an indicator of technological innovation: a review. Sci. Public Policy 19, 357-368.

Archibugi, D., Coco, A., 2005. Measuring technological capabilities at the country level: A survey and a menu for choice. Res. Policy 34, 175-194. https://doi.org/10.1016/j.respol.2004.12.002

Arundel, A., Kemp, R., 2009. Measuring eco-innovation Working Paper Series Measuring eco-innovation.

Beltramello, A., Haie-Fayle, L., Pilat, D., 2013. Why New Business Models Matter for Green Growth. Paris, Fr. OECD 01, 1-107. https://doi.org/10.1787/5k97gk40v3In-en

Botta, E., Koźluk, T., 2014. Measuring Environmental Policy Stringency in OECD Countries. OECD Econ. Dep. Work. Pap. https://doi.org/10.1787/5jxrjnc45gvg-en

Carlsson, B., Jacobsson, S., Holmén, M., Rickne, A., 2002. Innovation systems: analytical and methodological issues. Res. Policy 31, 233-245.

Castellacci, F., Natera, J.M., 2013. The dynamics of national innovation systems: A panel cointegration analysis of the coevolution between innovative capability and absorptive capacity. Res. Policy 42, 579-594. https://doi.org/10.1016/j.respol.2012.10.006

Castellacci, F., Natera, J.M., 2011. A new panel dataset for cross-country analyses of national systems, growth and development (CANA). Innov. Dev. 1, 205-226.

De Montalvo, U.W., Alaerts, G., 2013. Leadership in knowledge and capacity development in the water sector: A status review. Water Policy 15, 1-14. https://doi.org/10.2166/wp.2013.109

Eco-Innovation Observatory (EIO), 2016. Policies and Practices for Eco-Innovation Up-take and Circular Economy Transition.

Edquist, C., 2006. Systems of Innovation: Perspectives and Challenges. Oxford Handb. Innov. https://doi.org/10.1093/oxfordhb/9780199286805.001.0001

European Commission, 2016. R \& D Investments and Structural Changes in Sectors. Quantitative and Qualitative Analysis Policy Recommendations. Brussels. https://doi.org/10.2777/7318

Faber, J., Hesen, A.B., 2004. Innovation capabilities of European nations: Cross-national analyses of patents 
and sales of product innovations. Res. Policy 33, 193-207.

Fagerberg, J., Srholec, M., Knell, M., 2007. The competitiveness of nations: Why some countries prosper while others fall behind. World Dev. 35, 1595-1620.

Fan, P., 2011. Innovation capacity and economic development: China and India. Econ. Chang. Restruct. 44, 49-73.

Foxon, T., Kemp, R., 2008. Innovation impacts of environmental policies, in: The International Handbook on Environmental Technology Management. Edward Elgar Publishing, pp. 119-139.

Freeman, C., 1995. The 'National System of Innovation'in historical perspective. Cambridge J. Econ. 19, 524.

Furman, J.L., Porter, M.E., Stern, S., 2002. The determinants of national innovative capacity. Res. Policy 31, 899-933. https://doi.org/10.1016/S0048-7333(01)00152-4

Geels, F.W., 2004. From sectoral systems of innovation to socio-technical systems: Insights about dynamics and change from sociology and institutional theory. Res. Policy 33, 897-920.

Geels, F.W., 2002. Technological transitions as evolutionary reconfiguration processes: a multi-level perspective and a case-study. Res. Policy 31, 1257-1274.

Gregersen, B., Johnson, B., 2009. Stimulating sustainable energy innovation through policy learning and joint action, Joint Action on Climate Change Aalborg.

Gregersen, B., Johnson, B., 1997. Learning Economies, Innovation Systems and European Integration. Reg. Stud. 31, 479-490. https://doi.org/10.1080/00343409750132270

Griliches, Z., Pakes, A., Hall, B.H., 1986. The value of patents as indicators of inventive activity. National Bureau of Economic Research Cambridge, Mass., USA.

Gu, S., Lundvall, B.-A., 2006. China's Innovation System and the Move Toward Harmonious Growth and Endogenous Innovation. Innov. Manag. Policy Pract. 8, 1-26. https://doi.org/10.5172/impp.2006.8.1.1

Gu, S., Schwag Serger, S., Lundvall, B.Å., 2016. China's innovation system: ten years on. Innov. Manag. Policy Pract. 18, 441-448. https://doi.org/10.1080/14479338.2016.1256215

Horbach, J., Oltra, V., Belin, J., 2017. Industry and Innovation Determinants and Specificities of EcoInnovations Compared to Other Innovations-An Econometric Analysis for the French and German Industry Based on the Community Innovation Survey Determinants and Specificities of EcoInnovations Compared to Other Innovations-An Econometric Analysis for the French and German Industry Based on the Community Innovation Survey 1. https://doi.org/10.1080/13662716.2013.833375

Horbach, J., Rammer, C., Rennings, K., 2011. Determinants of Eco-innovations by Type of Environmental Impact The Role of Regulatory Push / Pull , Technology Push and Market Pull Determinants of Ecoinnovations by Type of Environmental Impact The Role of Regulatory Push / Pull , Technology Push and M. https://doi.org/10.2139/ssrn.1805765

Hu, M.-C.C., Mathews, J.A., 2008. China's national innovative capacity. Res. Policy 37, 1465-1479. https://doi.org/10.1016/j.respol.2008.07.003

Hu, M.-C.C., Mathews, J.A., 2005. National innovative capacity in East Asia. Res. Policy 34, 1322-1349. https://doi.org/10.1016/j.respol.2005.04.009 
Kemp, R., 2010. Eco-innovation: Definition, measurement and open research issues. Econ. Polit. 27, 397420. https://doi.org/10.1428/33131

Kemp, R., Andersen, M.M., 2004. EU key strategies MERIT-Riso final report 2004.

Kemp, R., Arundel, A., 1998. Survey Indicators for Environmental Innovation, Indicators and Data for European Analysis (IDEA) Project Report Series.

Kemp, R., Pearson, P., 2007. Final report MEI project about measuring eco-innovation. UM Merit, Maastricht 32, 121-124.

Kemp, R., Pontoglio, S., 2011. The innovation effects of environmental policy instruments-A typical case of the blind men and the elephant? Ecol. Econ. 72, 28-36.

Kemp, R., Soete, L., 1992. The greening of technological progress. Futures 24, 437-457. https://doi.org/10.1016/0016-3287(92)90015-8

Krammer, S.M.S., 2009. Drivers of national innovation in transition: Evidence from a panel of Eastern European countries. Res. Policy 38, 845-860.

Li, W., 2009. Eco-Innovation Policies in The People's Republic of China, Country profiles on policies to support environment-friendly innovation.

Liu, X., White, S., 2001. Comparing innovation systems: a framework and application to China's transitional context. Res. Policy 30, 1091-1114. https://doi.org/10.1016/S0048-7333(00)00132-3

Lundvall, B.-A., 1992. National innovation system: towards a theory of innovation and interactive learning. Pinter, London.

Lundvall, B.-Å., Vang, J., Joseph, K.J., Chaminade, C., 2009. Bridging innovation system research and development studies: challenges and research opportunities. Georgia Institute of Technology.

Lundvall, B.-å, 1998. Why study national systems and national styles of innovation? Technol. Anal. Strateg. Manag. 10, 403-422.

Lundvall, B.-äke, Johnson, B., 1994. The learning economy. J. Ind. Stud. 1, $23-42$.

Lundvall, B.-åke, Johnson, B., Andersen, E.S., Dalum, B., 2002. National systems of production , innovation and competence building 31, 213-231.

Lundvall, B., 2007. National Innovation Systems-Analytical Concept and Development Tool. Ind. Innov. 14, 95-119. https://doi.org/10.1080/13662710601130863

Mathews, J.A., Hu, M.C., 2007. Enhancing the Role of Universities in Building National Innovative Capacity in Asia: The Case of Taiwan. World Dev. 35, 1005-1020. https://doi.org/10.1016/j.worlddev.2006.05.012

Mellahi, K., Wilkinson, A., 2010. A study of the association between level of slack reduction following downsizing and innovation output. J. Manag. Stud. 47, 483-508.

Moro, M.A., Mcknight, U.S., Smets, B.F., Min, Y., 2018. The industrial dynamics of water innovation : A comparison between China and Europe. Int. J. Innov. Stud. 2, 14-32. https://doi.org/10.1016/j.jijis.2018.03.001

Natário, M.M., Couto, J.P.A., Tiago, M.T.B., Braga, A.M.M., 2007. Determinantes da capacidade nacional de inovação: uma análise à realidade européia, in: Conocimiento, Innovación y Emprendedores: Camino Al Futuro. Universidad de La Rioja, p. 115. 
Nelson, R., 1993. National innovation systems: a comparative analysis, University of Illinois at UrbanaChampaign's Academy .... Oxford University Press.

Nelson, R.R., 2006. Economic Development From the Perspective of Evolutionary Economic Theory. October 1-17.

Nelson, R.R., 1992. National innovation systems: a retrospective on a study. Ind. Corp. Chang. 1, $347-374$.

Nelson, R.R., Rosenberg, N., 1993. Technical innovation and national systems, in: National Inovation Systems: A Comparative Analysis. Oxford Press, pp. 3-22.

Nill, J., Kemp, R., 2009. Evolutionary approaches for sustainable innovation policies: From niche to paradigm? Res. Policy 38, 668-680. https://doi.org/10.1016/j.respol.2009.01.011

OECD, 2014. INVENTION AND INTERNATIONAL DIFFUSION OF WATER CONSERVATION AND AVAILABILITY TECHNOLOGIES: EVIDENCE FROM PATENT DATA.

OECD, 2012a. OECD Environmental Outlook to 2050: The Consequences of Inaction, Outlook, OECD Environmental Outlook. OECD Publishing. https://doi.org/10.1787/9789264122246-en

OECD, 2012b. Water and Green Growth, in: Water Innovation Europe. Brussels.

OECD, 2009. Eco-Innovation Policies in The People's Republic of China. Environment Directorade, OECD.

Oltra, V., 2008. Environmental innovation and industrial dynamics: the contributions of evolutionary economics. Cah. du GREThA 28, 27.

Pavitt, K., 1985. Patent statistics as indicators of innovative activities: Possibilities and problems. Scientometrics 7, 77-99. https://doi.org/10.1007/BF02020142

Porter, M.E., Linde, C. van der, 1995. Toward a New Conception of the Environment-Competitiveness Relationship. J. Econ. Perspect. 9, 97-118. https://doi.org/10.1257/jep.9.4.97

Porter, M.E., Stern, S., 1998. National Innovative Capacity. Harv. Bus. Rev. 37, 1465-1479. https://doi.org/10.1016/j.respol.2005.04.009

Proksch, D., Haberstroh, M.M., Pinkwart, A., 2017. Increasing the national innovative capacity: Identifying the pathways to success using a comparative method. Technol. Forecast. Soc. Change 116, 256-270. https://doi.org/10.1016/j.techfore.2016.10.009

Radosevic, S., 2002. Regional innovation systems in Central and Eastern Europe: determinants, organizers and alignments. J. Technol. Transf. 27, 87-96.

Riddel, M., Schwer, R.K., 2003. Regional innovative capacity with endogenous employment: empirical evidence from the US. Rev. Reg. Stud. 33, 73.

Romer, P.M., 1990. Endogenous technological change. J. Polit. Econ. 98, S71-S102.

Schiuma, G., Lerro, A., 2008. Knowledge-based capital in building regional innovation capacity. J. Knowl. Manag. 12, 121-136.

Suarez- Villa, L., 1990. Invention, inventive learning, and innovative capacity. Syst. Res. Behav. Sci. 35, 290310.

Suarez-Villa, L., 2003. The e-economy and the rise of technocapitalism: networks, firms, and transportation. Growth Change 34, 390-414.

United Nations Environmental Program (UNEP), 2011. Decoupling Natural Resource Use and Environmental 
Impacts from Economic Growth. A Report of the Working Group on Decoupling to the International Resource Panel. Fischer-Kowalski, M., Swilling, M., von Weizsäcker, E.U., Ren, Y., Moriguchi, Y., Crane, W., Krausmann, F., Eisenmenger, N., Giljum, S., Hennicke, P., Romero Lankao, P., Siri. sewage discharges to support EU Water Framework Directive ambitions in natural water bodies. 
786 Table A 1:List of countries used in the regression

\begin{tabular}{l|l|l}
\hline \multicolumn{2}{l}{ Country } \\
\hline Austria & Germany & Norway \\
\hline Belgium & Greece & Poland \\
\hline Bulgaria & Hungary & Portugal \\
\hline China (People's Republic of) & Ireland & Romania \\
\hline Croatia & Italy & Slovak Republic \\
\hline Czech Republic & Latvia & Slovenia \\
\hline Denmark & Lithuania & Spain \\
\hline Estonia & Luxembourg & Sweden \\
\hline Finland & Malta & United Kingdom \\
\hline France & Netherlands & \\
\hline
\end{tabular}

Table A 2:Description of the variables used in this paper

\begin{tabular}{|c|c|c|c|}
\hline Variable & Definition & Source & $\begin{array}{l}\text { Year } \\
\text { Frame }\end{array}$ \\
\hline \multicolumn{4}{|l|}{ Innovative Output } \\
\hline Patents & Green International water patents & PATSAT/ OECD & $\begin{array}{l}1990- \\
2013\end{array}$ \\
\hline Patents Pop & International patent per million persons & & $\begin{array}{l}1990- \\
2013\end{array}$ \\
\hline \multicolumn{4}{|c|}{ Quality of the common innovation infrastructure } \\
\hline GDP per capita & GDP in thousands of ppp-adjusted market prices & OECD & $\begin{array}{l}1990- \\
2013\end{array}$ \\
\hline Patent stock & Cumulative Patents & & $\begin{array}{l}1990- \\
2013\end{array}$ \\
\hline Population & Total inhabitants & OECD/UN & $\begin{array}{l}1990- \\
2013\end{array}$ \\
\hline FTEs\&E & Aggregate employed S\&T & OECD & $\begin{array}{l}1990- \\
2013\end{array}$ \\
\hline$R \& D$ & Aggregate R\&D expenditures (US Dollars) & OECD & $\begin{array}{l}1990- \\
2013\end{array}$ \\
\hline Openness & $\begin{array}{l}\text { Openness to international trade }=\text { exports (US } \\
\text { Dollars) }\end{array}$ & OECD & $\begin{array}{l}1990- \\
2013\end{array}$ \\
\hline IP & Strength of protection for IP & $\begin{array}{l}\text { International } \\
\text { property rights index }\end{array}$ & $\begin{array}{l}1990- \\
2013\end{array}$ \\
\hline ED share & $\begin{array}{l}\text { Share of government on higher education ( on } \\
\text { secondary and tertiary education divided by } \\
\text { GDP) }\end{array}$ & Eurostat & $\begin{array}{l}1990- \\
2013\end{array}$ \\
\hline $\begin{array}{l}\text { Strength of environmental } \\
\text { Regulation }\end{array}$ & Environmental policy stringency index & OECD & $\begin{array}{l}1990- \\
2012 \\
\end{array}$ \\
\hline Governance & Direct investment as \% of GDP (US Dollars) & OECD & $\begin{array}{l}1990- \\
2013\end{array}$ \\
\hline \multicolumn{4}{|l|}{ Cluster-specific environment } \\
\hline Private $R \& D$ funding & $\begin{array}{l}\text { Expenditure on R\&D of business enterprise-sector } \\
\text { divided by total expenditure on R\&D (US Dollars) }\end{array}$ & OECD & $\begin{array}{l}1990- \\
2013\end{array}$ \\
\hline
\end{tabular}




\begin{tabular}{|c|c|c|c|}
\hline Specialization & $\begin{array}{l}\text { Environmental Water technologies divided by } \\
\text { total Water patents }\end{array}$ & & $\begin{array}{l}1990- \\
2013\end{array}$ \\
\hline \multicolumn{4}{|l|}{ Quality of linkages } \\
\hline $\begin{array}{l}\text { Universities R\&D } \\
\text { performance }\end{array}$ & $\begin{array}{l}\text { Percentage of R\&D performed by high education } \\
\text { as percentage of total R\&D expenditure US } \\
\text { dollars) }\end{array}$ & OECD & $\begin{array}{l}1990- \\
2013\end{array}$ \\
\hline $\begin{array}{l}\text { Private R\&D funding } \\
\text { performed by Universities }\end{array}$ & $\begin{array}{l}\text { Private R\&D performed by high education as } \\
\text { percentage of total Private R\&D expenditure (US } \\
\text { dollars) }\end{array}$ & OECD & $\begin{array}{l}1990- \\
2013\end{array}$ \\
\hline Collaboration & International Collaboration index & OECD & $\begin{array}{l}1990- \\
2013\end{array}$ \\
\hline \multicolumn{4}{|c|}{ Contributing and related outcome factors } \\
\hline LABOR & $\begin{array}{l}\text { Number of full-time equivalent persons employed } \\
\text { in the labor force }\end{array}$ & OECD & $\begin{array}{l}1990- \\
2013\end{array}$ \\
\hline CAPITAL & Non-residential Capital stock (US Dollars) & OECD & $\begin{array}{l}1990- \\
2013\end{array}$ \\
\hline MARKET Share & $\begin{array}{l}\text { Share of exports on total (worldwide) trade in } \\
\text { water technologies }\end{array}$ & OECD & $\begin{array}{l}1990- \\
2013\end{array}$ \\
\hline Journal & Number of scientific publications & Web of Science & $\begin{array}{l}1990- \\
2012\end{array}$ \\
\hline Water quality & $\begin{array}{l}\text { Percentage of improvements on drinking water } \\
\text { quality }\end{array}$ & UNEP GEODATA & $\begin{array}{l}1990- \\
2013\end{array}$ \\
\hline Water dependency ratio & $\begin{array}{l}\text { Index of level of external water resources a } \\
\text { country depends on. }\end{array}$ & UNEP GEODATA & $\begin{array}{l}1990- \\
2013\end{array}$ \\
\hline Emnox & Nitrogen emissions & UNEP GEODATA & $\begin{array}{l}1980- \\
2008\end{array}$ \\
\hline EmSo2 & Phosphorus emissions & UNEP GEODATA & $\begin{array}{l}1980- \\
2008\end{array}$ \\
\hline emmvoc & & UNEP GEODATA & $\begin{array}{l}1980- \\
2008\end{array}$ \\
\hline
\end{tabular}


WP

$\begin{array}{lrrr}\text { Wpcap } & 0.5495 & 1 & \\ \text { specdgree } & -0.1088 & 0.1377 & 1\end{array}$

$\begin{array}{llll}\text { ESPindex } & 0.4067 & 0.5063 & -0.1687\end{array}$

$\begin{array}{lll}\text { pop } & 0.3954 & -0.5376\end{array}$

uniRD

PrivRDUni

GDPcap

\section{GovRD}

waterqua

Collaborate

emnox

emso2

emmvoc

iprights

waterdep
$0.3954-0.5376$

$\begin{array}{ll}-0.03 & -0.0005\end{array}$

$0.0982 \quad 0.1711$

$0.39410 .7866 *$

$0.751 * \quad 0.0249$

$0.17880 .7551 *$

$0.813 * \quad 0.2651$

$0.4561 \quad-0.4572$

$0.4561 \quad-0.4572$

$0.4499 \quad-0.417$

$0.59350 .6683 *$

$-0.0247 \quad 0.1057$ $\begin{array}{lr}-0.1687 & 1 \\ -0.2725 & -0.1525\end{array}$

$-0.1948$

$-0.1498$

$-0.1836$

$-0.4453$

0.0739

$-0.3747$

$-0.2874$

$-0.2874$

$-0.2136$

$-0.2502$

0.0339 $\begin{array}{lll}0.1106 & -0.0698 & 0.0826\end{array}$

$0.7485 * \quad-0.4681 \quad 0.1796$

$0.2423 \quad 0.7333 * \quad 0.0368$

$0.4087 \quad-0.6331 \quad 0.1184$

$\begin{array}{llll}0.4769 & 0.5326 & -0.0394\end{array}$

$\begin{array}{lll}-0.1492 & 0.9729 * & 0.0409\end{array}$

$\begin{array}{lll}-0.1492 & 0.9729 * & 0.0409\end{array}$

$\begin{array}{lll}-0.1928 & 0.9202 * & 0.0298\end{array}$

$\begin{array}{llll}0.3201 & -0.1585 & -0.0282\end{array}$

$\begin{array}{lll}0.0379 & -0.1414 & -0.2743\end{array}$

$\begin{array}{rrr}1 & & \\ 0.2342 & 1 & \\ 0.0742 & 0.0929 & 1 \\ 0.3381 & 0.7708^{*} & -0.1884 \\ 0.1427 & 0.356 & 0.8159^{*} \\ -0.087 & -0.4034 & 0.7636^{*} \\ -0.087 & -0.4034 & 0.7636^{*} \\ -0.1158 & -0.4036 & 0.7174^{*} \\ 0.0688 & 0.4799 & 0.3357 \\ 0.1975 & 0.0125 & -0.0982\end{array}$

$\begin{array}{rrrr}1 & & & \\ 0.0184 & 1 & & \\ -0.5629 & 0.5325 & 1 & \\ -0.5629 & 0.5325 & 1 & 1 \\ -0.5506 & 0.4661 & 0.9478^{*} & 0.9478^{*} \\ 0.2772 & 0.4437 & -0.0845 & -0.0845 \\ 0.144 & 0.1045 & -0.2707 & -0.2707\end{array}$

1

$-0.0277$

$-0.2721 \quad 0.1581$ 